Alma Mater Studiorum - Università di Bologna DEPARTMENT OF ECONOMICS

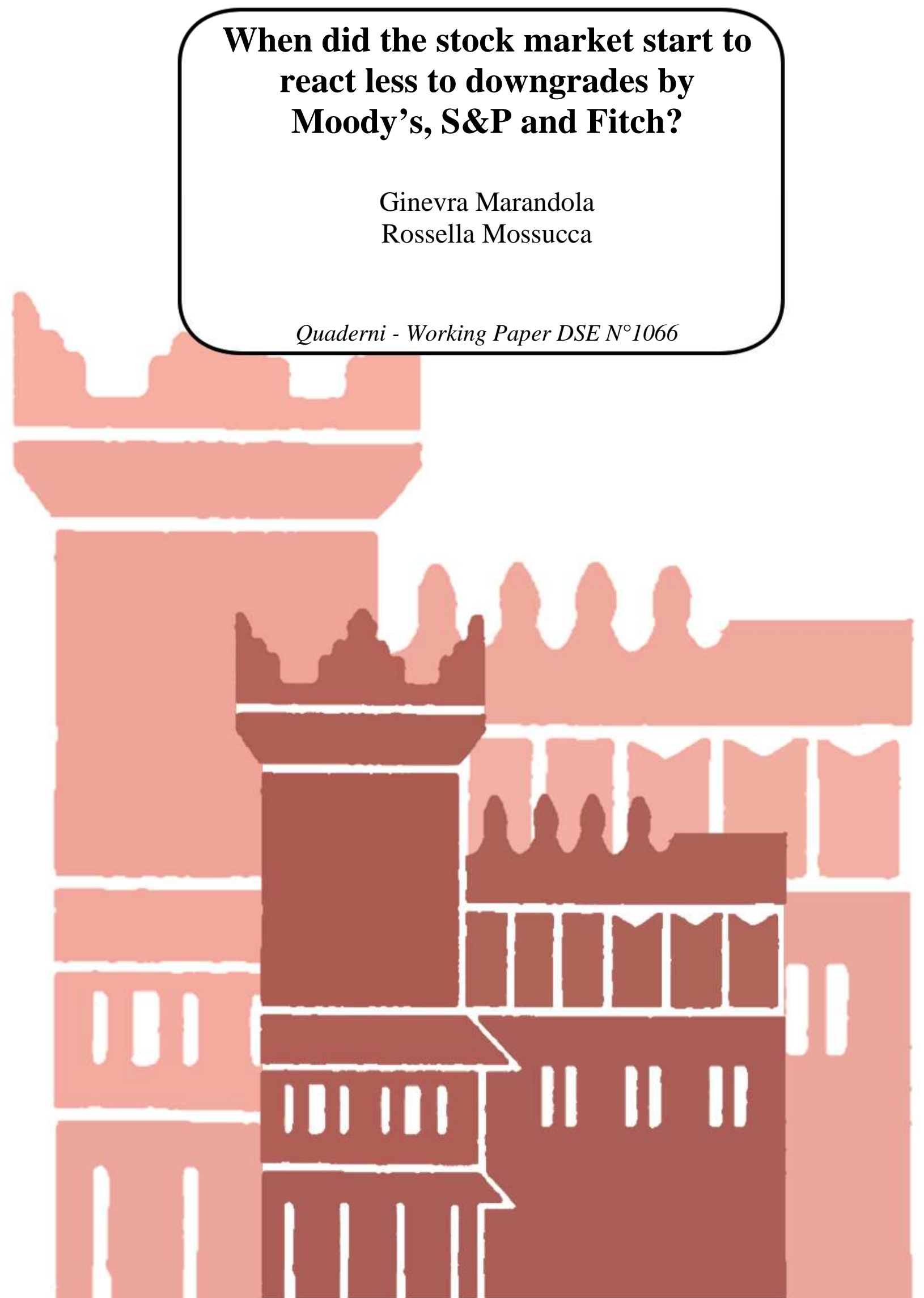




\title{
When did the stock market start to react less to downgrades by Moody's, S\&P and Fitch?
}

\author{
Ginevra Marandola ${ }^{1}$ and Rossella Mossucca ${ }^{2}$
}

This version: March, 2016.

\begin{abstract}
This paper studies the stock market response to corporate downgrades by S\&P, Moody's and Fitch between 1999 and 2011. The empirical evidence shows that cumulative abnormal returns around downgrades become significantly smaller (in absolute value) after the release in 2003 of the Securities and Exchange Commission's Report on credit rating agencies. The Report addresses concerns related to the agencies and marks a turning point in the attitude of U.S. regulators towards a more critical approach. This has a strong impact on investors that respond by reacting less to downgrades.
\end{abstract}

Keywords: credit rating agencies; credit ratings; stock market information; event study.

JEL classification: G14; G24; G28.

\footnotetext{
${ }^{1}$ Department of economics, University of Bologna. Piazza Scaravilli 2, 40126, Bologna, Italy. ginevra.marandola@gmail.com, ginevra.marandola@unibo.it, tel.: +393287433987

${ }^{2}$ Department of Economics and Finance, University of Rome Tor Vergata. Via Columbia 2, 00133, Rome, Italy. EIEF, Via Sallustiana 66, 00187, Rome, Italy. rossellamossucca@gmail.com, tel.: +393396266073
} 


\section{Introduction}

Moody's, S\&P and Fitch represent an oligopoly in the credit rating business, accounting for 94 percent of the global market (Candelon et al., 201) and for about 96.5 percent of all the outstanding ratings in U.S. ${ }^{3}$ The three agencies are key players in financial markets as they assess the credit worthiness of almost any debt issuer including governments, firms, municipalities and financial institutions. This paper focuses on ratings assigned to corporate debt, through which Moody's, S\&P and Fitch heavily affect corporate financing. The economic literature has shown that bond ratings are strongly correlated with private bond yields (Hand et al., 1992; Hite and Warga, 1997) and also to stock returns of debt issuers (Bannier and Hirsh, 2010; Dichev and Piotroski, 2001; Holthausen and Leftwich, 1986). Indeed, besides the issuer's ability to repay debt, private bond ratings signal future profit opportunities, reliability as a business partner and more in general the value of the firm.

As Spatt (2009) remarks "Casual empiricism suggests that even after the dramatic weakening of the credit rating agency reputations ratings downgrades still engender substantial price reactions - suggesting that investors continue to view somewhat seriously the information reflected in ratings changes." ${ }^{4}$ We believe that a focused study of the significance of price reactions to downgrades over time is needed. Indeed we argue that changes in the financial environment over the last decade may have affected the stock market response to Moody's, S\&P and Fitch's rating announcements.

On a sample of 657 firms listed in the U.S. that experienced at least a downgrade from Moody's, S\&P and Fitch between 1999 and 2011 we test the significance of equity abnormal returns using an event study analysis where each event is represented by a downgrade. Through univariate and multivariate analysis we find a strong and significant decrease in the stock market response to

\footnotetext{
${ }^{3}$ Annual Report (December, 2013) on Nationally Recognized Credit Rating Agencies of the Security and Exchange Commission to Congress under Section 6 of the Credit Rating Agency Reform Act of 2006.

${ }^{4}$ Spatt (2009), p. 697
} 
downgrades at the beginning of 2003 (Figure 1) after the Security and Exchange Commission (SEC) Report on Credit Rating Agencies issued in January 2003. The Report is the outcome of a study mandated to the SEC, in response to the Enron scandal, by the Sarbanes-Oxley Act (SOX) of 2002 in order to assess "the role of credit rating agencies in the evaluation of issuers of securities" and "the importance of that role to investors and the functioning of the securities markets." ${ }^{5}$ The Report represents a turning point for the rating business in U.S. and highlights several potential issues affecting the quality of ratings, such as conflict of interests and low competition. In other words, the Report signals the regulator's acknowledgment of the need to reform the business.

We identify three phenomena involving the rating business that are captured by the Report and that may be responsible for the reduction of the stock market reaction to rating changes. First of all, the Report is a clear negative signal sent by the regulator about the reliability of credit rating agencies. Second, it reinforces the negative impact that the Enron and WorldCom scandals in 2001 and 2002 had on credit rating agencies' reputation as they failed to foresee the companies' defaults. Third, in response to the Report the credit rating agencies may have updated their methodologies and policies to maintain the status quo and to regain trust (Baghai et al., 2014; Cheng and Neamtiu, 2009). Therefore, the Report may have had an impact on market reaction to downgrades through a change in the behavior of the agencies and/or directly affecting investors' beliefs. Our hypothesis is that the decrease in correlation between stock returns and downgrades by Moody's, S\&P and Fitch after the Report is due to a reduction in the information content of rating changes relative to the overall informational environment available to investors. Investors, especially institutional ones, have greater incentives to anticipate rating changes after the Report

\footnotetext{
${ }_{5}^{5}$ Pub.L. 107-204, 116 Stat. 745, enacted July 30, 2002. Title VII. Studies and Reports. Sec. 702. Commission study and report regarding credit rating agencies. pp. 798-799.
} 
and are facilitated to do that by the growing of the market for CDSs and the greater diffusion of other sources of financial information.

The growth of the market for CDSs may be an explanation of the decrease in market reaction to downgrades that we find. We do not deny this possibility, rather we identify it as a channel through which investors anticipate/substitute rating changes. However we show that the decrease in market reaction to downgrades that we find cannot be entirely explained by the increase in CDSs. Alternative explanations for the decrease in the stock market reaction to downgrades after the Report such as a reduction in risk aversion over time which leads to lower negative reaction to negative news, or a change in the magnitude of rating changes or the increased use of watch lists, are not supported by our empirical results. Given the length of the period under analysis, we also account for other events that may have affected market reaction to rating changes before and after the SEC's Report. The most relevant being the Credit Rating Agencies Reform Act of 2006 approved with the aim to improve the quality of ratings by increasing competition and transparency. We show that the Reform does not drive any of the results we find.

Finally, as suggested by Goh and Ederington (1993), we treat downgrades associated with negative abnormal returns separately from downgrades associated with positive abnormal returns. Although the literature widely acknowledges and explains this asymmetric response to downgrades (Avramov et al., 2009; Goh and Ederington, 1993; Holthausen and Leftwich, 1986), to the best of our knowledge, this is the first paper that applies this distinction in the empirical analysis. This approach gives much more insights on the magnitude of the stock market response because changes in the overall average of abnormal returns around downgrades may be driven by changes in the proportion and relative magnitude of negative abnormal returns vis à vis positive ones. We find that both positive and negative reaction to downgrades decreases in magnitude. A decrease in positive reactions to downgrades also helps excluding that the results we find are driven by lower reaction to negative news due to positive market sentiment in the years after the Report. 
We perform several robustness checks in order to support our motivation for the decrease in market reaction to rating changes but we do not exclude that other phenomena may contribute to it. Notwithstanding, we argue that one of the reasons why after 2003 the market reacts less to rating changes' announcements is that investors believe that they convey less information to them.

The remainder of the paper is organized as follows. In the next section we present how this paper fits and contributes to the existing literature. In Section 3 we explain our methodological approach. In Section 4 we introduce data sources and some descriptive statistics. In Section 5 we present the results of the empirical analysis. In Section 6 we perform several robustness checks. In Section 7 we conclude by further discussing the interpretation of results and the alternative explanations.

\section{Literature Review}

This work is related to that strand of literature that analyzes the effects that rating changes have on the equity market. Holthausen and Leftwich (1986), a seminal paper in this field, measures the market response to rating changes by S\&P and Moody's from 1977 to 1982; Goh and Ederington (1999) uses Moody's rating changes from 1984 to 1990 to analyze the difference in stock market reaction between investment grade and speculative grade securities; Purda (2007) analyzes stock market reaction to Moody's downgrades from 1991 to 2002 distinguishing between anticipated and unanticipated downgrades; Jorion and Zhang (2007) analyzes stock response to S\&P and Moody's rating changes from 1996 to 2002 controlling for the rating prior to the announcement. These studies show significant stock market reactions around downgrades and absent or weak market reaction to upgrades. More recent studies on this topic are Bannier and Hirsch (2010) whose sample period includes downgrades from 1982 to 2004; Xia (2014) that covers a period going from 1999 to 2011. Bannier and Hirsch (2010) identify two economic functions of rating reviews: for low rated firms the watch list is used as a monitoring device that gives incentive not to incur in further risk, while for high quality issuers the authors interpret rating downgrades and the watch list as instruments to provide information. As a consequence, 
Bannier and Hirsch (2010) show that the stock market responds less to a watch-preceded downgrade than to a direct downgrade for speculative grade securities while this finding does not hold for investment grade securities. Xia (2014) shows an increase in the quality of ratings issued by S\&P on firms also covered by Egan Jones suggesting that competition by an investor-paid agency increases the incumbent's reputational concerns. The author also finds increased stock market response to rating changes issued by S\&P for firms covered by Egan Jones.

The impact of regulation on the rating business has been studied before in different settings. On a sample period from 1998 to 2002, Jorion et al. (2005) investigate whether the informational content of ratings has changed after the Fair Disclosure reform of 2000 thanks to which Credit Rating Agencies (CRAs) were allowed to receive privileged private information by issuers. The authors conclude that private information, valuable to investors, gave CRAs a privileged position with respect to other analysts. On a sample of Moody's, S\&P and Fitch credit ratings from 1996 to 2005, Cheng and Neamtiu (2009) examine how rating agencies respond to increased regulatory pressure by looking at differences in timeliness and accuracy of ratings before and after the Sarbanes-Oxley bill was passed. Overall, they find enhanced timeliness in the sample of defaulted issues. The authors also find enhanced accuracy in predicting either ex-post defaults or very high default risk deterioration (or improvement), along with unchanged or even reduced rating volatility. Hence, for defaulted issuers and for firms experiencing relatively greater credit quality deterioration results are consistent with the idea that the three agencies have improved their credit analysis under both metrics from the second half of 2002 to the end of December 2005, against the claim of a trade-off between timeliness and long term accuracy. The authors do not exclude, however, the possibility that the increased accuracy of ratings is partly due to the larger disclosure imposed on corporate firms by the Sarbanes-Oxley Act. Bruno et al. (2014) compare the ratings of Moody's, S\&P and Fitch (issuer-paid agencies) to the ones of Egan Jones (EJR) which is an investor-paid agency that obtained formal recognition after the Credit Reform Act of 2006. In line with Beaver et al. (2006) they find that EJR issues more timely and accurate ratings than the big three, both before and after the recognition. Basing on this evidence, Bruno et al. (2012) maintain 
that it is the business model (i.e. conflict of interests) rather than the $\mathrm{NRSRO}^{6}$ recognition at the origin of the big three lower performance. Kisgen and Strahan (2010) study the effect of the NRSRO recognition on bond yields. The authors focus on DBRS, a Canadian agency that was recognized NRSRO by the SEC in 2003. Kisgen and Strahan (2010) find that after the SEC's recognition of DBRS firms for which ratings by DBRS are higher than the ones of the incumbents show a decrease in bond yields, while bond yields do not increase for firms that DBRS rates less favorably than the incumbents. The authors also find that this phenomenon is stronger for bonds that are at the threshold between the investment grade and the speculative grade. Kisgen and Strahan (2010) suggest that these results, together with further analysis in the paper, are evidence of an impact of the recognition on yields. The authors also offer some descriptive evidence about the fact that after the recognition as NRSRO the ratings issued by DBRS are closer to the ones of the incumbents.

The impact of scandals on CRAs' reputation and performance is also widely studied. Allen and Dudney (2008) find that Moody's dominance in the market of local government bonds drops between 1993 and 1997 in response to the investigation of the Justice Department on Moody's. The agency had been accused by issuers to use unsolicited ratings to threat potential clients and make them demand for the agency's ratings. Hill (2009) finds a psychological explanation for the fact that many investors still rely on credit ratings after Enron. The author argues that "an adaptive trait-incorporating new data that potentially conflicts with one's pre-existing worldview so as to preserve as much of that worldview as possible-proved to be maladaptive in this circumstance.7" The author states that before Enron the view was that rating agencies were sound and Enron was accounted for the product of fraud and complexity. Moreover the change in climate

\footnotetext{
${ }^{6}$ A Nationally Recognized Statistical Rating Organization (NRSRO) is a credit rating agency (CRA) whose ratings are officially recognized as reference for credit worthiness by the U.S. Securities and Exchange Commission (SEC).

${ }^{7}$ Hill (2009) p. 283-284
} 
and regulation made market participants confident that such an error would have been less likely to occur again. Another explanation for this phenomenon is that investors do not consider defaults of high rated firms as a good proxy of rating quality. Indeed, Löffler (2013b) finds that the stock price of Moody's suffers big losses when the agency announces rating reversals but investors do not seem to react to defaults of highly rated firms. This result is either consistent with collusion between sophisticated investors, issuers and the agencies or with investors' misconception of how to evaluate the quality of ratings.

Another important factor that may affect the rating business is the presence of alternative information and thus the ability of investors to complement or substitute ratings and evaluate their quality. Norden and Weber (2004), find that both the CDS market and the stock market anticipate rating downgrades around two or three months before the announcement because "[...] reference entities are subject to permanent market monitoring". ${ }^{8}$ Hull et al. (2004), also show that CDS spread changes anticipate downgrades by Moody's. Flannery et al. (2010) test empirically the strength of CDS as a substitute for credit ratings in the discovery of prices. The analysis, at both aggregate and firm level, supports the conclusion that CDS spreads reflect information more quickly and accurately than credit ratings. Overall, the authors suggest that different market measures of risk may be exploited together. For instance, synthetic measures, like implied credit spreads can be used together with CDS to outperform ratings in price discovery. However, Flannery et al. (2010) analysis shows that no as easy at hand measure is available as credit ratings are. Löffler (2004a) empirically shows that ratings have a low short-term predictive ability, which increases with horizon (Löffler, 2004b); hence investors should use different sources of information for short-term risk. Chava et al. (2015) show that the stock market reacts significantly less to downgrades when the downgraded security has an associated CDS. The authors propose four main channels explaining the phenomenon: 1) CDS spreads anticipate rating downgrades; 2) CDS spreads are useful in predicting defaults3) the CDS market allows price discovery in the

\footnotetext{
${ }^{8}$ Norden and Weber (2004) p. 2838
} 
stock and bond markets before downgrades' announcements 4) the term structure of CDSs enables investors to measure a default risk premium better than credit ratings.

On investors' use of the information conveyed by ratings Avramov et al. (2009), Baghai et al. (2014), Dilly and Mahlmann (2015) and Mahlmann (2011) are worth citing. Avramov et al. (2009) finds that the price underperformance in the seven months surrounding a downgrade is driven by stocks of worst rated firms that were overpriced by myopic retail investors and whose prices strongly adjust around downgrades because of high illiquidity, selling pressure of institutional investors and short sale constraints. This mispricing explains what the authors call 'credit risk effect', that is the negative correlation between credit risk and stock returns. Avramov et al. (2009) show that the negative market reaction to downgrades is attributable to low rated firms, while high rated firms show on average positive returns. Baghai et al. (2014) studies agencies' behavior over the period 1985 to 2009 and finds that they have become more conservative over time in corporate ratings. The authors also show that firms that are more affected by this conservatism have lower bonds yields than firms with the same rating and characteristics. Baghai et al. (2014) claim that this occurs because investors believe that ratings overstate default risk. Dilly and Mahlmann (2015) find a significantly lower correlation between ratings and bond spreads during periods of booms and suggest that this is due to the fact that investors have different views (more pessimistic) with respect to the agencies. Mahlmann (2011) finds that bond yields for bonds that are issued by firms that have long term relationships with the agencies are higher and less correlated with ratings suggesting that investors consider ratings for these firms less informative.

\section{Methodological approach}

\subsection{The SEC's Report}

The empirical analysis aims at testing the impact of the "SEC's Report on the Role and Function of Credit Rating Agencies" on the stock market response to downgrades. The SEC's report, issued in January 2003, is a formal investigation mandated by the Congress in response to failures of the 
credit rating agencies to foresee big defaults (i.e. Enron in October 2001 and WorldCom in July 2002). The report covers the following issues: “(A) the role of credit rating agencies in the evaluation of issuers of securities; (B) the importance of that role to investors and the functioning of the securities markets; $(\mathrm{C})$ any impediments to the accurate appraisal by credit rating agencies of the financial resources and risks of issuers of securities; (D) any barriers to entry into the business of acting as a credit rating agency, and any measures needed to remove such barriers; (E) any measures which may be required to improve the dissemination of information concerning such resources and risks when credit rating agencies announce credit ratings; and (F) any conflicts of interest in the operation of credit rating agencies and measures to prevent such conflicts or ameliorate the consequences of such conflicts."

Given its content and the context in which it was issued, the Report represents an alert to market participants about the actual reliability of ratings and a signal of the regulator's awareness of the need to reform the business. The relevance of this Report rests on the fact that it represents a turning point for the regulators' attitude towards the incumbent agencies. Indeed, until the issue of the Report, financial regulators had strongly relied on the agencies considering their ratings as a reference for credit quality. Bond ratings were incorporated in financial regulation for the first time in 1931 as reference measures of the quality of national banks bonds' holding and since then many U.S. Federal Agencies referred to ratings in their regulatory provisions. In 1973 the Security Exchange Commission (SEC) introduced the category of Nationally Recognized Statistical Rating Organizations (NRSROs) and until 2003 only 3 organizations were designated as such: Moody's, Standard \& Poor's and Fitch. The Report is the first official action through which the regulators cast doubts on the role of credit rating agencies as watch dogs of financial markets. We expect the impact of this to be strong and resounding, thus affecting investors' beliefs. Moreover, one month after the Report in February 2003 the SEC decides to recognize Dominion Bond Rating

\footnotetext{
${ }^{9}$ See footnote 5 .
} 
Services (DBRS) as the fourth national rating organization. ${ }^{10}$ Similarly the recognition represents a strong signal of the regulators' commitment to pursue an increase in competition in the rating business. Thus, it reinforces the message of the Report. In addition, the recognition of DBRS may have given incentives to the incumbents to make changes in their methodologies and standards in order to hold their market power, thus affecting the equity response to rating changes through a change in the characteristics of ratings. However, Kisgen and Strahan (2010) find that ratings issued by DBRS get closer to the ratings of the incumbents after 2003, but it is DBRS that adapts to the incumbents' ratings and not vice versa. Therefore, our preferred hypothesis is that the Report directly had an impact on investors and that this did not happen through a change in the agencies' behavior. In this respect, Löffler (2013b) measures the effect that rating reversals have on Moody's reputation by studying the movements of Moody's stock around reversal announcements. Reversals are perceived by investors as a proxy of low quality of ratings. The author finds that, beyond the subprime crisis, the greatest negative reactions to reversals occur around June 2002 (the coefficient is based on observations from June 2001 to June 2003) and suggests that this can be the effect of the SEC hearing on credit rating agencies of November 2002 (the Report issued in January 2003 is the result of that hearing). ${ }^{11}$ This is perfectly in line with our results, investors become more distrustful towards credit rating agencies after the Report. The negative signal sent by the SEC with the Report is strong and resounding, especially because it follows the Enron and WorldCom scandals and it is issued in a period of reforms, such as the Sarbanes Oxley Act, that aim at making financial markets more transparent in order to protect

\footnotetext{
10 "The Enron and WorldCom disasters prompted a shake-up of the rating industry. U.S. regulators feared the financial system was relying on too few ratings agencies [...]. The shake-up was a break for DBRS. It had been trying since 1990 to expand into the U.S. market, but had been turned away by regulators loath to give it the coveted NRSRO designation. Thanks to Enron et al., the Canadian agency was finally admitted to the club in 2003”. (Robertson, G., 2012. Is DBRS right on Europe? http://www.theglobeandmail.com, accessed Oct. 27, 2012)

${ }^{11}$ See Fig. 3, p. 163.
} 
investors. Therefore the impact of the Report is potentially very strong in particular for institutional investors whose reliance on ratings is partly due to regulatory constraints or recommendations. Institutional investors hold a great share of securities, thus their actions are strongly reflected on the stock market. The Report highlights an important trade-off which is intrinsic in the business, namely the trade-off between stability and timeliness of ratings. The incumbent agencies have acknowledged the existence of this trade-off and seem to defend stability at the cost of timeliness as the latter increases volatility in financial markets and may have a causal negative effect on firms' access to funds (Moody's 2003; Moody's 2006). Löffler (2013a) provides empirical evidence that the agencies use a through-the-cycle approach and this justifies their delay in responding to new information. On the other hand, the lack of timeliness represents a cost for investors, even accounting for the positive effect of reduced volatility, as shown by Cornaggia and Cornaggia (2013). The authors claim that Moody's action are too biased towards stability not because of the agency's objective to reduce volatility but because of the conflicts of interest generated by the issuer-pays model. The Report discusses this issue and in light of the Enron and WorldCom scandals it leads investors to reckon the agencies to be biased in favor of the interests of the issuers. ${ }^{12}$

\subsection{Empirical strategy}

\subsubsection{Model for excess returns}

We measure the market response to downgrades using stock abnormal returns surrounding the date of the announcement. ${ }^{13}$ Abnormal returns are defined as the difference between the daily

\footnotetext{
${ }^{12}$ For example, a survey performed by The Association of Financial Professionals confirms that in 2004 relatively few treasury and finance professionals believed "ratings favor interests of investors". Credit Rating Agency Survey 2004, www.afponline.org, p.3.

${ }^{13}$ To measure the information content of rating announcements we choose to study the stock market reaction to bond downgrades rather than the bond yields. Indeed, the former is mainly affected by investors' evaluation of rating's information as opposed to the bond market response to rating changes that is instead more contaminated by regulatory and self-regulatory constraints. Such constraints may
} 
stock return $R_{i, t}$ and the corresponding expected return $\mathrm{E}\left(R_{i, t}\right)$ evaluated using the linear market model: ${ }^{14}$

$R_{i t}=\alpha_{i}+\beta_{i} R_{m t}+\epsilon_{i t}$

[1]

The model is estimated using OLS over a six month 'estimation window' that ends two days before each downgrade to avoid overlapping with the 'event window' which is of five days around the announcement of any downgrade. ${ }^{15}$ Abnormal returns in the event window around downgrade announcements for each firm $i$ are defined as the difference between observed returns and the market model predicted returns:

$\widehat{A R}_{i \tau}=\boldsymbol{e}_{i \tau}=\boldsymbol{R}_{i \tau}-\widehat{\boldsymbol{\alpha}}_{i}-\widehat{\boldsymbol{\beta}}_{i} \boldsymbol{R}_{m \tau}$

[2]

indeed cause automatic bond portfolio rebalancing at given rating thresholds independently of the information conveyed by the rating change (Partnoy 1999, 2007; White, 2010). Moreover the stock market is more liquid and thus allows to perform a more precise analysis from a statistical point of view. We also studied but do not report results on upgrades. Consistently with prior studies (e.g. Goh and Ederington, 1999; Holthausen and Leftwich, 1986), we do not find significant effects of upgrades on stock market returns.

${ }^{14} \mathrm{We}$ alternatively defined abnormal returns as the difference between the daily stock return $R_{i, t}$ and the corresponding value-weighted market index return $R_{m, t}$ (market adjusted model). As a further robustness check we alternatively evaluated expected returns using the three-factor Fama and French model (Fama and French, 1993) and its extension to four factors proposed by Carhart (1997). Results are qualitatively the same among the three models.

${ }^{15}$ We repeat our analysis using a different estimation window, also including a post-event period (from $\tau-k-120$, to $\tau+k+120$, excluding $k$ days before and $k$ days after any event date $\tau$ where $k$ goes from -2 to +2 ). We do this "to increase the robustness of the normal market return measure to gradual changes in its parameters.” (MacKinlay 1997, p. 20). Results are qualitatively the same. 
The event window is defined for $\in[-2,2]$, where $\tau=0$ is the day of a downgrade announcement. We cumulate ARs over several days around the announcement date to capture news leak or delay in market response. CARs of firm $i$ are defined as:

$\operatorname{CAR}_{i}(-j,+k)=\sum_{\tau=-j}^{k} \widehat{A R}_{i \tau} \quad j, k \in[0,2]$

[3]

where $\mathrm{CAR}_{i}(-j,+k)$ can therefore span several combinations of ARs within the announcement window. There are several benefits from the choice of a narrow announcement window: it reduces the likelihood that the announcement effect is biased by the effect of other news (Holthausen and Leftwich, 1986); the use of short windows around the event, with well-defined event dates and daily data as in our sample, also makes results not very sensitive either to the specification of the benchmark model that defines counterfactual normal returns, or to assumptions of cross-sectional and time series independence (Holthausen and Leftwich, 1986; Kothari and Warner, 2007).

\subsubsection{Procedure}

First, we assess the significance of $\mathrm{C}(\mathrm{AR}) \mathrm{s}$ on windows of different lengths around the SEC's Report using univariate parametric and non-parametric tests. The univariate tests aim at showing that the decrease of the stock market response to downgrades occurs right after the issue of the SEC's Report. As a robustness check we control for changes in the stock market response to downgrades also on short term windows around other events related to the rating business: the Enron and WorldCom scandals, the Reform Act of 2006 and the Dodd-Frank Act of 2010. The multivariate analysis involves several steps. First, on the whole sample period from 1999 to 2011 we regress $\mathrm{C}(\mathrm{AR}) \mathrm{s}$ on firms' characteristics and downgrade's features that might explain the stock market reaction to downgrades (equation 4). In a second step, we add to the baseline model a dummy indicator for downgrades that occur the SEC's Report (sec) having taken place or not at the time of the downgrade (equation 5). In this way we test a change in the estimated intercept after the Report controlling for other factors that may explain average $\mathrm{C}(\mathrm{AR}) \mathrm{s}$ variation. Both CARs and the explanatory variables are observed only on downgrades' days thus the 
intercept may be interpreted as the effect of the downgrade on CARs controlling for downgrade's and firm's characteristics. We also test the model in equation 4 by splitting the sample in downgrades that are observed before the SEC's report and after in order to check for discontinuities in the correlation between the covariates and the dependent variable.

$\mathrm{C}(\mathrm{AR})_{\mathrm{i}, \mathrm{t}}=\alpha+\mathrm{B}_{1}{ }^{\prime} \mathbf{X}_{\mathrm{it}}+\mathrm{B}_{2}{ }^{\prime} \Gamma_{\mathrm{i}}+\mathrm{B}_{3}{ }^{\prime} \mathbf{Z}_{\mathrm{t}}+\varepsilon_{\mathrm{it}}$

[4]

$\mathrm{C}(\mathrm{AR})_{\mathrm{i}, \mathrm{t}}=\alpha+\mathrm{B}_{1}{ }^{\prime} \mathbf{X}_{\mathrm{it}}+\mathrm{B}_{2} \mathbf{s e c}_{\mathrm{t}}+\mathrm{B}_{3}{ }^{\prime} \Gamma_{\mathrm{i}}+\mathrm{B}_{4}{ }^{\prime} \mathbf{Z}_{\mathrm{t}}+\varepsilon_{\mathrm{it}}$

[5]

$X_{i t}$ is the vector of explanatory variables and controls, $\sec _{t}$ is the dummy variable for the Report, $\Gamma_{i}$ are industry fixed effects, $\mathrm{Z}_{t}$ are dummies that capture financial crisis or other events related to the rating business.$^{16}$ In order to exclude that our results are attributable to other events that directly regarded credit rating agencies we repeat the analysis in equation 5 excluding all the downgrades that take place after the Reform Act of 2006. This allows us to exclude the confounding effects of the Reform and of other events that followed it, such as the financial crisis and the Dodd-Frank Act.

Finally, in order to exclude that results are driven by changes in the proportion and relative magnitude of negative and positive market responses to downgrades, we split the sample into downgrades characterized by negative cumulative abnormal returns and downgrades characterized by positive abnormal returns and test the model in equation 5 .

\footnotetext{
${ }^{16}$ We estimate all econometric models using White robust standard errors to account for heteroscedasticity, or alternatively cluster standard errors around firm and year.
} 
We perform multivariate regressions using as dependent variables abnormal returns on the announcement day $\operatorname{AR}(0)$ and cumulative abnormal returns for the announcement day plus the day before and the day after CAR(-1,1). ${ }^{17} \mathrm{We}$ only report multivariate analysis for CARs.

\section{Data and Descriptive Statistics}

\subsection{Data}

We include in the sample all US non-financial firms listed on the New York Stock Exchange, the American Stock Exchange and NASDAQ, whose outstanding debt experienced at least one downgrade by S\&P, Moody's and Fitch from August 1998 to April 2011. We collect from Mergent Fixed Investment Securities Database (FISD) information on bond ratings. Stock prices, market indexes and the information concerning firms (industry, status, stock exchange, market to book value, market capitalization, debt to equity, debt to total assets, number of employees, dividend yield and return on equity) are collected from DataStream.

Firms in our sample represent a large share of the total market capitalization of the above stock exchanges (i.e. on average, 40 percent of NYSE). We exclude Yankee bonds and bonds issued through private placement. We also exclude rating changes when the indicated reason is a merger or acquisition because we are not able to disentangle the effect of the M\&A from the effect of the rating change. We excluded from the sample firms for which the daily stock prices are missing or with insufficient trading days before the downgrade to ensure the estimation of expected stock returns using the market model. Our sample is thus composed by 657 firms, 1756 bonds and 3023 downgrades from February 1999 to April 2011.

\subsection{Descriptive statistics}

\footnotetext{
${ }^{17}$ The day before is included in CARs to account for a possible anticipation of the news, while the day after is included to account for the fact that the downgrade might indeed be announced at the end of the trading day.
} 
We show the distribution of $\mathrm{C}(\mathrm{AR}) \mathrm{s}$ around downgrades announcement dates in Table 1 . We expect average $\mathrm{C}(\mathrm{ARs})$ to be negative after a downgrade. However, as highlighted by Holthausen and Leftwich (1986), if the downgrade was expected to be of a larger than actual magnitude by the market, the corresponding $\mathrm{C}(\mathrm{AR})$ may be positive. Positive $\mathrm{C}(\mathrm{AR}) \mathrm{s}$ after positive news (smaller than expected downgrade) may indeed be an indication of undervalued stocks and may reflect the delayed adjustment due to the surprising news (Qian, 2014). Moreover, Goh and Ederington (1993) argue that whenever a transfer of wealth is expected from bondholders to stockholders the corresponding $\mathrm{C}(\mathrm{ARs})$ may be positive. For example, $\mathrm{C}(\mathrm{ARs})$ following a downgrade might be positive because the downgrade signals an increase in firm's leverage or gambling for survival at the low end of the scale, which would increase the value of the equity. In our sample, $43 \%$ of downgrades results in positive CARs (and between $44 \%$ and $48 \%$ of ARs). We test the significance and the sign of $\mathrm{C}(\mathrm{AR}) \mathrm{s}$ around downgrades with both parametric (tstatistic) and non-parametric tests on the whole sample (Table 1). Non parametric tests include a) the sign-rank test, b) the testing procedure proposed by Corrado (1989) and c) the GRANK procedure proposed by Kolari and Pynnönen (2010). ${ }^{18}$ As shown in Table 1, on the overall sample, $\mathrm{C}(\mathrm{AR}) \mathrm{s}$ for downgrades are statistically different from zero and with negative sign, according to all tests performed.

\footnotetext{
${ }^{18}$ In the sign-rank test, the null hypothesis is that negative and positive CARs have the same mean rank. The Corrado rank test is based on the uniform distribution of rankings of excess returns under the null hypothesis of no mean effect; however its "relative power advantage [with respect to parametric tests] is expected to decline with longer return intervals" (Corrado 1989 p.395), i.e. with CARs. The GRANK (generalized rank) is a testing procedure for both ARs and CARs and has been developed especially to deal with cumulative abnormal returns in event studies; it has several advantages with respect to other non-parametric testing procedures, as it is shown to be robust to serial autocorrelation of stock returns, to event induced higher volatility and to some extent of cross-sectional correlation when event days are clustered across firms. It is based on the distribution of standardized ranks of ARs and CARs around the median rank, under the null hypothesis of no mean effect.
} 
[Insert Table 1 around here]

Most firms in our sample (76\%) are rated by more than one agency and $37 \%$ is rated by all three agencies. There are instances in our sample of two or even all three agencies downgrading bonds issued by a given firm on the same date. However, we actually want to measure the effect of a single downgrade, with no confounding effects, that might be related to the fact that downgrades announced on the same day by more than one agency are somewhat different. For example, they might be related to an extremely severe deterioration of firms' prospects, be the consequence of information released by the firm or news leak suddenly showing in the news, or be related to extraordinary corporate operations or events. In order to eliminate possible contamination effects, we restrict our analysis to firm-observations for which there is no overlapping in the same day of downgrades from different credit rating agencies. ${ }^{19}$ By doing so we lose 130 downgrades and are left with 2893 downgrades. In Table 2 we report the transition matrix of bonds in our sample along the rating scale before (rows) and after (columns) the downgrade. Our sample covers all rating categories, but securities are concentrated in the middle classes (from A to CC) as common in the literature. The number of extreme ratings is balanced, 21 securities are rated D and 20 securities are in the AAA category.

[Insert Table 2 around here]

Table 3 shows descriptive statistics of the variables that we use in the analysis and that can be correlated with $\mathrm{C}(\mathrm{AR}) \mathrm{s}$ around downgrades.

[Insert Table 3 around here]

In line with the existing literature we transform the credit ratings issued by the three agencies into a cardinal scale: 1 is equivalent to AAA (Aaa) for S\&P and Fitch (Moody's), 2 is equivalent to $\mathrm{AA}+(\mathrm{Aa} 1)$ for S\&P and Fitch (Moody's) and so on, until 21 which is equivalent to C and 23

\footnotetext{
${ }^{19}$ We also perform (but do not report) the analysis without dropping those observations, and results are the same.
} 
which is equivalent to D for S\&P and Fitch. ${ }^{20}$ We use the cardinal scale to measure the size of the downgrade as the difference between the outstanding rating after the downgrade and the one before. Hence the variable rchange indicates the number of notches a security is downgraded by (in absolute value). $67 \%$ of downgrades in our sample are of only one notch, and the maximum rating change is of 12 notches. The variable days equals the number of days elapsing between two downgrades referring to the same firm, and it is a proxy for the frequency of rating information about a company flowing to the market. The variable negative watch is a dummy variable equal to one when the downgrade is preceded by a negative watch, i.e. a statement that the rating will be under review and an indication that the most likely result of the review will be a downgrade. $28 \%$ of downgrades in our sample are preceded by a negative watch. Threshold is a binary variable equal to one if as a consequence of the downgrade a bond is revised from investment grade to speculative grade. Investment grade is a dummy equal to one if the downgraded security was deemed investment grade before the downgrade. The mean of the dummy investment grade represents the share $(56 \%)$ of securities rated investment grade before the downgrade whatever the category they fall within thereafter, while the mean of threshold tells us that $13 \%$ of downgrades implies a revision from investment grade to speculative grade: therefore, about $22 \%$ of investment grade securities is downgraded to a speculative grade. Other variables in Table 2 are firm characteristics that we use as further controls for sample composition effect: employees (total number of workers as of the end of the year before the downgrade) is a variable that should capture firm size effects; market capitalization (the number of a company's outstanding shares times the share price six days before the downgrade) is also a proxy for firm size, but in addition it reflects investors' expectations about future prospects embedded in the share price; market to book is the ratio between a firm's market capitalization and its accounting value, and should

\footnotetext{
${ }^{20} \mathrm{~S} \& \mathrm{P}$ indicates default with the letter D and Fitch has three default ratings: D/DD/DDD. In order to have just one number for the default category we assign 23 to all of them, which corresponds to DD following Fitch's scale. Moody's does not provide a default category. Our sample has few defaults; therefore this choice does not have important implications on our results.
} 
capture the effect of undervalued vs. overvalued firms; roe (net income as a percentage of common equity as of the end of the year before the downgrade) is an indicator for profitability; debt to equity and debt to capital (the debt to common equity and debt to total capital ratios refer to the end of the year before the downgrade) are controls for potential leverage variation in the sample that might affect results as long as more leveraged companies are riskier, and have a relatively greater outstanding debt whose yields are affected by changes in ratings; dividend yield (the ratio between annual dividends paid per share, and the share price) refers to six days before the downgrade and should capture sample variation in dividend policies. A list of the industries to which firms in the sample belong is reported at the end of Table 2. The sample is quite balanced across sectors with the most represented ones being Industrial Goods and Services, Retail, Utilities and Personal and Households goods.

Table 4 reports the descriptive statistics for the main downgrade's characteristics before and after the SEC's Report and the results of t-tests on the difference of means pre and post.

[Insert Table 4 around here]

The number of downgrades and the number of downgrades preceded by a negative watch significantly increases after the SEC's Report, whereas the number of investment grade securities significantly decreases (in line with findings in Baghai et al., 2014). However, the average size of the downgrade and the number of securities that cross the threshold do not vary with the SEC's Report.

\section{Results}

\subsection{Univariate Results}

As shown in Figure 1, cumulative abnormal returns in the three day-window around the downgrade announcement show a significant decrease at the beginning of 2003. Before 2003 CARs are much more variable and larger implying stronger reaction to downgrades; while they get closer to zero after 2003. The reduction is quite symmetric for positive and negative CARs. 
Indeed maximum and minimum CARs before 2003 are respectively around 50\% and $-52 \%$ compared with a maximum of $33 \%$ and a minimum of $-37 \%$ after the SEC's Report.

[Insert Figure 1 around here]

Figure 2 shows CARs around downgrades grouping them in trimesters, several events regarding the rating business are signaled on the on the $\mathrm{x}$-axis. The average CAR on the whole sample is $1.3 \%$ which is below the average CAR observed before $2003(2 \%)$ and above the average CAR observed after the first semester of $2003(0.8 \%)$.

[Insert Figure 2 around here]

To test if the decrease in the market reaction to downgrades occurs close to the SEC's Report release we repeat the parametric and non-parametric tests in Table 1 over windows of 12 months and 18 months centered on the release of the Report (results in Table 5). Short windows around the Report enable us to exclude other events that may have affected market reaction to rating downgrades. ${ }^{21}$ Parametric and non-parametric tests in Table 5 provide a strong evidence of a substantial reduction in the market reaction to downgrades in the short term after the SEC's Report.

[Insert Table 5 around here]

As shown in Table 5, the mean of CARs on the three day event window is of $-4.8 \%$ in the 6 months before the SEC's Report versus an average CAR of $0.5 \%$ (non-statistically different from zero) in the six months after the SEC's Report. The same trend is detected on CARs on the 18 month window and ARs on both the 12 month and 18 month windows. The average absolute reduction for $\mathrm{C}(\mathrm{AR}) \mathrm{s}$ is of 5.3 percentage points ( 2.3 percentage points) in the 6 months postSEC and of 3.5 percentage points (1.5 percentage points) in the 9 months post-SEC. The sign-

\footnotetext{
${ }^{21}$ The SEC's Report (January 2003) has been issued few months after Enron (October 2001) and WorldCom (June 2002) scandals.
} 
rank and the Z-GRANK show that $\mathrm{C}(\mathrm{AR}) \mathrm{s}$ around downgrades are significantly negative and lower than the median in the 6 months and 9 months before SEC's Report but not in the 6 months and 9 months right after. After the SEC's Report C(AR)s around downgrades tend to zero and lose almost any statistical significance.

The univariate results show that the market response to downgrades significantly decreases in the short term after the SEC's Report of 2003.

In order to check that changes in average C(AR)s are not associated with changes in the CRAs' behavior that lead to shifts in the main characteristics of downgrades, we compare averages of the main explanatory variables before and after the SEC's Report in Table 6.

[Insert Table 6 around here]

As shown in Table 6 the average of the main downgrades' characteristics does not significantly change across the two short windows around the SEC's Report according to a standard t-test. A lower proportion of ratings preceded by a negative watch (Negative Watch) in the 9-month window after the SEC's Report is the only statistically significant change. Watch lists are used by rating agencies to differentiate and increase the information they supply to financial markets, therefore a different proportion of watch preceded downgrades may induce different $C(A R) s$. However the change would have implied opposite results on abnormal returns with respect to the ones observed, as a lower proportion of ratings preceded by a negative watch implies larger abnormal returns..$^{22}$ Notwithstanding, we repeat the tests on average CARs before and after the Report only on downgrades not preceded by a negative watch (Table 7). The reduction in average

\footnotetext{
${ }^{22}$ Holthausen and Leftwich (1986) find that watch-preceded downgrades "provide less information than rating changes not preceded by Credit Watch announcements" p. 79. Bannier and Hirsch (2010) find that for lower quality firms "the market reacts much less strong to a watch-preceded downgrade than to a direct rating change" (p. 3039).
} 
$\mathrm{C}(\mathrm{AR}) \mathrm{s}$ is confirmed when repeating the analysis only on direct downgrades hence we can claim that results are not driven by the change in the number of watch-preceded downgrades.

[Insert Table 7 around here]

\subsection{Multivariate Results}

First we perform cross-sectional multivariate regressions to test how the main downgrade's features explain variations in average CARs on the entire sample period, from 1999 to 2011, controlling for firm's characteristics. ${ }^{23}$ Results are reported in Table $8 .{ }^{24}$ Columns 1 to 5 include an increasing number of explanatory variables and controls. Rchange, in line with the literature, has a negative coefficient for downgrades, the larger the absolute magnitude of the downgrade the larger the average stock price decline. ${ }^{25}$ The coefficient estimate is statistically different from zero at the 5\% level and quite stable across all specifications. Over the entire sample period the marginal effect on average CARs of an additional notch downgrade implies an extra excess return ranging from $-0.5 \%$ to $-0.6 \%$. The coefficient on negative watch is significant and positive (the marginal impact measured by the coefficient ranges from $1.3 \%$ to $1.6 \%)$. Since, as pointed out by Bannier and Hirsch (2010), the percentage of ratings on watch has increased over time, it is important to control for such phenomenon to exclude that the reduction in average CARs has been driven by the increase in the number of credit watches. We also allow for a different impact of downgrades on excess returns depending on the investment vs. speculative grade status of securities prior to the rating change (investment grade), and for the crossing of the investment grade category caused by the downgrade (threshold). We find that the average marginal effect of a downgrade on CARs for securities rated investment grade is less negative with respect to

\footnotetext{
${ }^{23}$ Multivariate analysis is performed both on CARs and ARs but given the limited space we do not report regressions on the latter. They are available upon request.

${ }^{24}$ We use White robust standard errors to account for heteroscedasticity, or alternatively cluster standard errors around firm and year (not reported).

${ }^{25}$ Hand et al. (1992); Holthausen and Leftwich (1986); Jorion et al. (2005).
} 
speculative grade securities (the coefficient is statistically significant and ranges from $1.3 \%$ to $1.4 \%$ ), while crossing the threshold implies a more negative impact (statistically significant coefficient around $-2 \%$ ). Results on variables tracking the investment grade status before and after the downgrade are mixed in the literature, but many authors agree that the coefficient should be positive for higher grade securities ${ }^{26}$ and negative for those crossing the investment grade status ${ }^{27}$, in line with results in this paper. The crossing of the investment grade threshold is associated with stronger market reaction because of several regulatory restrictions which force institutional investors to sell speculative grade securities or heavier requirements for financial institutions that hold low rated securities. ${ }^{28}$ Lower market reaction for high rated firms is attributed to several reasons: there is more information in the market for high rated securities, thus downgrades might be more easily anticipated; low rated firms that are downgraded become relatively "less attractive as a takeover candidate" so that they generate greater reaction than high rated firms; ${ }^{29}$ high rated firms are less likely mispriced (Avramov et al., 2009); and changes in default probability from one rating class to another may be non-linear thus generating different reactions according to the starting rating (Jorion and Zhang, 2007). The variable days is positive and significant suggesting

\footnotetext{
${ }^{26}$ Hand et al. (1992) find that in the contaminated sample, the mean stock CAR "for below investment grade bonds are reliably more negative than for investment grade bonds" (p.746). However, in their regression of bond excess returns the investment grade dummy it is not statistically significant. Avramov et al. (2009) find that high rated securities are less affected by small investor's overpricing thus showing positive stock returns on average around downgrades.

${ }^{27}$ Holthausen and Leftwich (1986) find that in the non-contaminated sample of downgrades, crossing the investment grade threshold has a marginal impact which is significantly negative, but not in the contaminated sample. Jorion et al. (2005) find that the variable indicating revisions from above to below investment grade has a significant negative impact.

${ }^{28} \mathrm{Hand}$ et al. (1999) argue that "if there are separate clienteles for investment and below-investment grade bonds, rating changes that cross the investment/below-investment grade boundary should result in stronger excess returns" (p. 748).

${ }^{29}$ Goh and Ederington, 1999, p. 109.
} 
that closer downgrades generate greater reaction, maybe because they indicate serious financial distress and the inability to recover. The crisis of 2001 (crisis01) and the financial crisis (crisis07) are added to control for the business cycle. ${ }^{30}$ In columns 2 to 5 we add further firm level controls for size, leverage and profitability. ${ }^{31} \mathrm{We}$ always control for the identity of the rating agency issuing the downgrade and for industry effects.

[Insert Table 8 around here]

In columns 1-2 of Table 9, we explore whether the reduction in CARs after 2003 holds when explicitly accounting for downgrade features and firm's characteristics. We first introduce a binary indicator for $2003 \mathrm{sec}$ ) in column 1 of Table 9. In light of the results of the univariate analysis, we expect the coefficient on the dummy to be positive, confirming that after 2003 there is a reduction in average CARs. The dummy indicator for the publication of the 2003 SEC's Report is associated with a significant and positive coefficient. At the $1 \%$ significance level, estimates suggest that after the SEC's Report, ceteris paribus, the average CAR is shifted up by +1.7 percentage points with respect to the previous sample period. This is a sizeable effect when taking into account that the average CAR in the full sample period is $-1.55 \%$. In column 7 we then add dummies to control for other events that involved the rating business over time: the FD regulation (October 2000); the Enron scandal (October 2001); the Reform Act of 2006 (September 2006); the Dodd-Frank Act (July 2010). These events do not show any significant incremental effect with the exception of the Dodd-Frank Act whose coefficient turns out to be positive and significant at the $10 \%$ level. The Dodd-Frank Act's Section dedicated to CRAs focuses on the level of public oversight and accountability, standards of liability and conflicts of interest. A

\footnotetext{
${ }^{30}$ We control for the two official recessions - as defined by NBER - of March to November 2001 and December 2007 to July 2009 recorded over the period covered by our sample, adding two binary indicators.

${ }^{31} \mathrm{We}$ also try different variables from the ones reported in the paper as proxies of firms' dimensions and results are unchanged.
} 
further decrease in response to rating changes after the Act is not surprising as it removes reference to ratings in financial regulation and other privileged treatments to which CRAs were subject. Finally we restrict the sample to downgrades announced before the Reform of 2006 (February 1999 - September 2006) as shown in column 3 of table 9. The coefficient on the dummy $s e c$ is not affected by the shortening of the sample. Results support the hypothesis that the decrease in average CARs detected in 2003 (after the SEC's Report publication) is not due to any influence of later events. In columns 4 and 5 of Table 9 we split the sample into downgrades observed before (column 4) and after (column 5) the SEC's Report to have insights on the changes of the explanatory power of downgrades' characteristics. We find that the size of the rating change and the dummy for the negative watch have smaller and non-significant coefficients after the SEC's Report. These two variables are related to the information content of ratings. The size of the downgrade gives information about the degree of creditworthiness deterioration and the negative watch allows investors to anticipate the downgrade and thus adjusting to it. It seems that these two sources of information are less relevant in the post-SEC period. The coefficient on the crossing of the threshold is also smaller and less significant after 2003. This result may be due to an anticipation effect. On the other hand the dummy for investment grade securities has a larger positive and significant effect in the post-SEC period. This might be explained by the fact that the increase in alternative information is stronger for high rated securities than speculative grade ones, thus downgrades to the former might be more easily anticipated using different sources of information in the post-SEC period. Alternatively the result may be due to an increase in the difference between the market reaction to downgrades to investment grade securities and the market reaction to downgrades to speculative ones. This may be due to a widening of the difference between default probabilities associated to investment grade securities and default probabilities associated to speculative grade securities after the SEC's Report. For example, Baghai et al. 2014 observe decreases in default probabilities over time more for investment grade securities than for speculative grade securities.

[Insert Table 9 around here] 
An alternative explanation to our results could be that after 2003 the reaction to downgrades shifts from being negative on average to being positive, driven for instance by a change in risk aversion, by underpricing rather than overpricing, or by changes in the risk profile of firms. Therefore, we study positive and negative CARs after downgrades separately (results reported in columns 1 and 2 of Table 10). The distinction between positive and negative CARs allows us to exclude a balance out between opposite sign CARs that results in CARs that overall are closer to zero. We find that after the SEC's Report both negative and positive CARs exhibit a significant decrease in absolute value, as indicated by the sign of the coefficient on the dummy sec which is positive for negative CARs and negative for positive CARs. This is a key finding because it supports the idea that the reduction in average CARs is not due to a change in the way in which investors respond to negative news, but it is rather due to a change in the significance of this response. Almost all explanatory variables have opposite signs on positive CARs with respect to negative CARs indicating that the effect is the same on both. The only exception is the dummy for the watch preceded downgrades that displays a positive coefficient both on negative CARs and positive CARs. This suggests that watch preceded downgrades generate less of a reaction than direct downgrades when the reaction is negative, while they generate a greater reaction than direct downgrades when the reaction is positive. The negative response to watch preceded downgrades is smaller because the information is somewhat anticipated by the negative watch. Conversely, the positive response may be greater because the surprising effect of smaller than expected downgrades may be even larger when the downgrade is preceded by a negative watch. Threshold is significant only for negative CARs. Crossing the threshold explains stronger negative reactions due to the regulatory constraints that force institutional investors to sell downgraded securities, but it hardly explains stronger positive stock abnormal returns. The financial crisis (crisis07) significantly exacerbates market reaction to both positive and negative CARs as a consequence of greater volatility and/or greater mispricing due to analysts' disagreement (Qian, 2014).

[Insert Table 10 around here] 
The decrease in both positive and negative market reaction to downgrades after 2003 provides evidence against a change in risk aversion that could be driving our results on the whole sample. If a decrease in risk aversion might explain a weaker reaction to bad news embedded in downgrades, it hardly explains smaller positive CARs. In the literature, positive CARs around bond downgrades are linked to the exploitation of trade-offs between equity holders and bond holders. Goh and Ederington (1993) for instance mention the case of a sustained increase in firm's leverage or firm's gambling for survival at the low end of the scale; Holthausen and Leftwich (1986) argue that if the downgrade was expected to be of a larger than actual magnitude by the market, the corresponding CAR may be positive. In such cases, lower risk aversion might lead to a stronger gambling in the market, hence to larger positive CARs on average. On the contrary, we do find that after SEC's Report in 2003 the average of positive CARs exhibits a significant negative shift (toward zero), symmetrically to negative $C(A R)$ s whose average displays a positive shift (toward zero). As a robustness check we also introduce in the baseline model a variable meant to control for investors' risk aversion. The "VIX", implied volatility of options on the S\&P 500 , is used to provide an indication of the amounts an investor is prepared to pay to protect herself from the risk of price fluctuations. The VIX, provided by the Chicago Board Options Exchange, is considered by many market analysts a direct measure of risk aversion. Moreover, Iannotta et al. (2013) use the VIX to capture cycles of high market uncertainty, when public information (including ratings) becomes less informative and investors are more willing to gather and price alternative (costly) private information. The authors indeed find that in periods of high market uncertainty ratings' ability to explain bond spreads decreases. Hence controlling for VIX also allow us to control for variation in investors' reliance on ratings due to cycles in market uncertainty. Adding the VIX leaves our results (not reported) unchanged.

\section{Robustness checks}

\subsection{Univariate Results}


As a robustness check we test for differences in the distribution of CARs around downgrades before and after other relevant events that may have affected the stock market response to downgrades. Table A.1 shows no evidence that CARs decrease (in absolute value) after Enron (Table A.1, Panel A) and WorldCom (Table A.1, Panel B) in the 18 month-window. ${ }^{32}$ These findings show that the stock market response to downgrades does not decrease right after the scandals. We compare CARs on downgrade days before and after the Reform of 2006 and the Dodd-Frank Act on windows of 18 months. The t-tests in Table A.1 (Panel C and Panel D) show a significant reduction (in absolute value) in average CARs after reform of 2006 and a large but not statistically significant decrease after the Dodd-Frank Act. These results confirm that regulatory interventions may have an impact on the stock market in the short run even before that the structural changes brought about by the reforms have the time to directly affect the market more persistently.

\subsection{Multivariate Results}

\subsubsection{Sub-sample analysis}

As a robustness check, we test the impact of the SEC's Report on average CARs on the subsample of direct downgrades, distinguishing between investment grade securities and speculative grade securities. We chose to exclude watch preceded downgrades because (as shown in Table 4) their number increases after 2003. Therefore, the average reduction in CARs that we detect may be driven by this phenomenon. Indeed, watch preceded downgrades are associated with smaller negative CARs (column 2 of Table A.2) and with bigger positive CARs (column 1 of Table A.2), thus with smaller CARs in absolute value. Within the group of direct downgrades we distinguish between investment grade securities and speculative grade securities. Investment grade securities are associated with less negative CARs, therefore the decrease in the number of investment grade securities after 2003 that we observe (Table 4) should lead to more negative CARs. Although the effect would be opposite to what we find, we still want to check for asymmetries in the effect of

\footnotetext{
${ }^{32}$ The analysis is repeated for the one year window and results are qualitatively the same.
} 
the Report between investment grade securities and speculative grade ones. Indeed, Baghai et al. (2014) show that default rates for all rating classes, excluding the worse ones, decrease over time. Showing that the SEC's report has an impact also on the worse classes may help at excluding that results are driven by changes in default rates. The coefficients on the SEC's Report are positive and significant in both columns confirming that the reduction in the stock market response to downgrades is not due to a change in the distribution of watch preceded downgrades and investment grade securities. This finding is important because direct downgrades capture the informative content of ratings better than watch preceded downgrades for which rating actions have also a monitoring role (Bannier and Hirsch, 2010). The coefficient on the interaction between the SEC's Report and the size of the downgrade is positive and significant for speculative grade securities. The coefficient has the same sign but is not significant for investment grade securities. This is not surprising because the size of the rating change is not significant for investment grade securities neither before the SEC's Report (the coefficient on rchange is not significant in column 1 of Table A.2) nor on the whole sample (not reported).

\subsubsection{Selection bias}

In line with the literature (Goh and Ederington, 1999; Holthausen and Leftwich, 1986; Jorion et al., 2005) we restricted the main analysis to CARs recorded on days when a downgrade is observed. However, the decrease in CARs around downgrades after the SEC's Report may be driven by lower abnormal returns after 2003 both on downgrade days and on other days (non rating change days). This may be due to a selection bias if the firms that belong to our sample (i.e. firms that have been downgraded at least once between 1999 and 2011) have lower returns also in days in which there are no downgrades. To exclude the possibility that the decrease in CARs around downgrades after 2003 is reflecting a time pattern common to the stock market returns in our sample, we exploit non rating change days as a control. Moreover, we also control for upgrades. We estimate the following regression pooling together both downgrade and non downgrade days (equation 6): 
$\mathrm{CAR}_{i, t}=\alpha+B_{1}$ down $_{i t}+B_{2} u_{i t}+B_{3} \sec _{t}+B_{4}\left(\sec _{t} * \operatorname{down}_{i t}\right)+B_{5}\left(\sec _{t} * \mathrm{up}_{i t}\right)+B_{6}^{\prime} X_{i t}+B_{7} \Gamma_{i}+B_{8}{ }^{\prime} \mathrm{Z}_{t}+$ $\varepsilon_{i t}[6]$

up and down are dummy variables equal to one for upgrades and downgrades respectively. We add the usual control covariates to the specification. To perform the analysis above we randomly select 6000 days in which there is no announcement by a credit rating agency, this is our "control" group. Then we add to the latter all the announcement days for downgrades and upgrades, this is our "treatment" group. The random selection procedure is performed so that all firms and years are represented in the new selected sample of rating change and non rating change days. The SEC's Report dummy (sec) captures the post-2003 effect in normal days, while the interaction with the dummy for downgrades (upgrades) captures the post-Report effect in downgrades (upgrades) days. In order for our results to be robust we repeat the analysis 100 times each time randomly selecting a new control group. Results in column 1 of Table A.3 confirm that downgrades occurring after January 2003 are associated with CARs of a lower magnitude, as the interaction term $s e{ }^{*}$ down is highly significant and with opposite sign with respect to the variable down, that instead captures the incremental effect of a downgrade before SEC's Report with respect to non-rating change observations. The coefficient on sec is not significant, supporting that the reduction in CARs after the Report holds only for rating announcement days actually identifying some 'change' in the market response to ratings, while average abnormal returns on other days do not vary with the SEC's Report. The coefficient on the dummy indicator for upgrades (up) is not significant as well as its interaction with $s e c$, thus no conclusion can be drawn on upgrades. This is not surprising since it is common in the literature to find not significant cumulative abnormal returns around upgrades (Goh and Ederington, 1999; Holthausen and Leftwich, 1986).

Finally, we want to exclude that the results are due to structural changes in risk aversion or to periods of positive market sentiment that lead to lower reactions to negative news thus explaining the decrease in the market reaction to downgrades ceteris paribus. We perform a simple robustness check to test if the SEC's Report has an effect also on market reaction to upgrades. In order to isolate any variation within upgrades that may not be captured in the pooled analysis, in column 
2 of Table A.3 we restrict the sample to upgrades and we distinguish between upgrades leading to negative CARs and upgrades leading to positive CARs:

$\mathrm{C}(\mathrm{AR})_{i, t}=\alpha+B_{1} \operatorname{neg}_{i t}+B_{2} \sec _{t}+B_{3}\left(\sec _{t} * \operatorname{neg}_{i t}\right)+B^{\prime}{ }_{4} X_{i t}+B_{5}^{\prime} \Gamma_{i}+B_{6}^{\prime} \mathrm{Z}_{t}+$ $\varepsilon_{i, t}$

The coefficient on sec suggests that positive CARs after upgrades decrease in magnitude after 2003, and the interaction term between sec and neg confirms a reduction in magnitude also for negative CARs around upgrades after the Report. Results in column 3 on downgrades are similar. This finding suggests that the reduction in the stock market response to downgrades is not due to positive market sentiment or peculiar to negative news since the same trend is detected for the market response to upgrades. Results are better explained by a decreasing market response to rating actions of the incumbent agencies.

\subsubsection{An alternative hypothesis: the market for CDSs}

Our hypothesis is that after the Sec's Report of January 2003, investors, especially institutional ones, consider the information conveyed by rating changes as less relevant to their investment decisions, thus reacting less to downgrades. We also claim that the growing diffusion of other sources of financial information contributes to the decrease in stock market reaction to rating changes because it allows the market to anticipate rating announcements. CDSs are one of the instruments that may complement or substitute ratings in price discovery (Norden and Weber 2004, Hull et al. 2004, Flannery et al. 2010). Chava et al. (2015) show that the stock market reacts significantly less to downgrades when the security has an associated CDS. They show that before 2001 no security in their sample is associated with a CDS and that the growth of the sample share of CDS traded securities is rapid afterwards. Hence our results may be driven by the growth in CDS traded securities in the sample. Since the diffusion of CDSs sharply increases in 2003, the dummy for the Report that we use in the empirical analysis may capture the jump in CDS traded securities rather than the effect of the Report itself. We think that both the increase in CDS and the Report explain the decrease we observe but we we perform a robustness analysis in order to exclude that the increase in CDSs in the only driving phenomenon. We use the 
distribution by year of CDS traded securities in the sample of Chava et al. (2015) as a control variable for the growth of the market for CDSs over our sample period. We exploit the fact that their sample of rating changes is drawn from the same data source (FISD) of our sample and that it similarly encompasses all U.S. domestic corporate debentures issued by firms whose stocks are traded on either the NYSE, AMEX, or NASDAQ (with identical restrictions). The time span of their data also overlaps to ours. Hence it is very likely that the rating changes in the two samples are mostly the same, except that Chava et al. (2015) also have information on contemporaneous trading of CDSs on firm's debt. In Table A.4 in the appendix we show the fraction by year of downgrades to securities associated to CDSs from Chava et al. (2015). We use this variable as a proxy of the proportion of downgraded securities associated with CDS in any given year in our sample. In column 1 of Table A.5. we show that the variable has a good explanatory power in our sample and that it has a positive sign as expected. The increase in the proportion of CDSs is correlated with the decrease in the absolute value of CARs around downgrades. As shown by Chava et al. (2015), downgrades to securities associated with CDSs generate less reaction in the stock market because CDSs anticipate rating announcements and defaults. In Table A.5 in the Appendix we test the variable of interest (sec) controlling for the proportion of CDSs. The coefficient on the dummy variable sec is still positive and significant and the magnitude is almost unchanged. On the other hand the proxy for CDSs is no longer significant and changes sign. The distribution of CARs in our sample is better explained by a sharp decrease around the Report in 2003 rather than a smoother positive trend after 2001. It can be that CDSs start affecting the stock market reaction in 2003 that is the year during which they register the greater increase. This is quite unlikely however because in 2004 and 2005 securities with CDS represent around the 50\% of the sample, thus weighting more on average CARs. To test this possibility we interact the proxy for the proportion of CDSs with the dummy sec that equals one since January 2003. The correlation between the proportion of CDSs and CARs is negative and not significant before 2003 as expected. The correlation after 2003 is positive but not statistically different from zero. 
However the dummy sec is still positive and significant suggesting that the decrease in CARs does not depend (at leat entirely) on the proportion of CDSs.

\section{$7 \quad$ Discussion of alternative hypotheses}

The univariate and the multivariate analysis show a decrease of average market response to rating changes after the SEC's Report release in January 2003. Our hypothesis is that the decrease is explained by the fact that investors perceive the information conveyed by rating changes as less relevant to their investment decisions. We also show that the size of the rating change, used in the literature to measure the informative content of ratings, does not significantly explain the size of the market reaction to downgrades after January 2003. In this section we try to support our identification of the reasons behind the decrease in market reaction to rating changes excluding alternative explanations in light of the empirical results presented so far.

Through the Report of 2003, the regulator signals a clear acknowledgement of distortions in the rating business and of the need to reform it. However the Report does not bring any formal change to the market of ratings. Therefore any evidence related to its issue shall not be a consequence of structural changes in the rating regulatory framework. Rather, the Report more likely triggered investors' skepticism toward Moody's, S\&P and Fitch, increasing awareness of the limits of ratings and leading to the sharp decrease in market response to downgrades. Alternatively to our hypothesis, the results provided in this paper may be explained by an adaptive response of Moody's, S\&P and Fitch to the SEC's Report of 2003 in order to avoid stricter regulation or to regain investors' confidence. Such a reaction would have resulted in a variation over time in the distribution of some of observable downgrade's characteristics. For instance, the rising adoption of credit watches is a way to more timely release information that eventually leads to formal ratings revision and might explain a diminishing impact of downgrades overall. We provide evidence in the univariate and the multivariate analysis excluding that our results are driven by an increasing adoption of credit watches in the short run. We control for other firm-level and 
downgrades' characteristics throughout the analysis. Thus, we exclude that our results are due to changes in the behavior of Moody's, S\&P and Fitch that imply changes in downgrades' size or in the rating level of firms ceteris paribus or in other observables. Notwithstanding, we are aware of empirical evidence that shows that the agencies have become more accurate (Cheng and Neamtiu, 2009) and more conservative (Baghai et al., 2014). The former shows that Moody's, S\&P and Fitch announce downgrades for firms that will default in a year more timely and assign lower ratings to them after SOX. First of all this should result in greater stock market reaction to downgrades since they are less likely anticipated. Second, our analysis includes securities from all the rating classes and does not focus on defaulted firms. It is not unlikely that the agencies increase their accuracy and timeliness more for very risky securities. Indeed, the agencies have greater incentives to better monitor worse issuers since scarce rating accuracy is more easily revealed if defaults actually occur (as it happened for Enron and WorldCom). Baghai et al. (2014) instead find that the credit rating agencies become more conservative over time and that the issuers that suffer more for this conservatism have lower spreads with respect to similar firms with the same ratings. The authors suggest that this is due to the fact that investor acknowledge excessive stringency and discount it, the market "undoes" the impact of conservatism. Although the authors find that this trend starts well before 2003 (in the 90's), still it may partly drive our results. Baghai et al. (2014) also show that default rates for all rating classes, excluding the worse ones, decrease over time. This finding may explain our results, if the quality of firms in each rating class increases and investors acknowledge more conservatism in ratings they may react less to downgrades. However, we control for firms' characteristics and rating levels in the multivariate analysis which should partly capture a shift in the composition of the sample and we show that the effect of the SEC's Report holds also for speculative grade securities which are less affected by changes in default rates. Finally, if default rates decrease linearly across categories after 2003 , the effect of a downgrade should be unchanged as it measures a relative increase in risk. Nonetheless, even assuming that our results are driven by the phenomenon described by Baghai et al. (2014), our conclusions still hold. Indeed, this change in the agencies' behavior only matters 
in terms of stock market reaction if it is acknowledged by investors. As Baghai et al. (2014) suggest if the increase in conservatism was fully warranted it would have been innocuous, thus only if investors do not fully trust ratings this change may affect their reaction to downgrades confirming our hypothesis.

We claim that the reduction of investor's reaction to downgrades has been made feasible by the availability of many alternative information sources such as public financial information flows and a wider variety of different financial products reflecting credit risk (e.g. CDS). ${ }^{33}$ In July 2002, right after the WorldCom debacle, the Sarbanes-Oxley Act (SOX) set new rules to enhance both quantitatively and qualitatively financial information released by public companies, accounting firms and security analysts. Other studies confirm that alternative sources of information are better than ratings at signaling default risk (Flannery et al., 2010), and may help anticipating rating actions (Hull et al., 2004; Norden and Weber, 2004). This does not exclude that less sophisticated investors still rely on ratings which are easier to interpret and obtain. Moreover in the robustness section, we show that the sharp increase in CDS contracts does not drive our results. Indeed, although the proxy for the diffusion of CDSs that we borrow from Chava et al. (2015) is positively correlated with CARs, the the stock market response to downgrades displays a negative shift in 2003 that is not explained by the growing trend in CDSs.

Alternative financial information may also include ratings issued by other competitors. However, the recognition of DBRS (the main Canadian CRA) among the NRSROs on February 2003 - right after the SEC's Report - per se did not represent a real threat to the established oligopoly of S\&P, Moody's and Fitch, as proven by the fact that DBRS remained a relatively small player in the market. This is not necessarily due to reputational capital, for example common standard practice

\footnotetext{
${ }^{33}$ Jakola (unpublished results) reports that according to the British Bankers Association (BBA) and the International Swaps and Derivatives Association (ISDA) the market for CDS increased from $\$ 180$ billion in notional amount in 1997 to \$5 trillion in 2004 ( Jakola, M. 2006. Credit Default Swap Index Options. Working Paper).
} 
represents a barrier to entry for new CRAs since, as reported in the survey by Cantor et al. (2007), guidelines for portfolio managers generally refer to specific rating agencies (more precisely to Moody's, S\&P and Fitch), rather than to NRSROs in general. Even if competition had increased, it would have been difficult for investors to assess its impact on rating quality, thus generating an ambiguous stock market response. Becker and Milbourn (2011) show that the entry of Fitch has a negative effect on rating's quality since the incumbents issue inflated ratings in order not to lose their customers. On the other hand, Lugo et al. (2014) suggests that herding behavior by Fitch is more common when revisions have to be made downwards and that Moody's and S\&P influence Fitch more than viceversa due to their larger reputational capital. Finally, Doherty et al. (2012) and Xia (2014) show that when investor-paid agencies compete with issuer-paid agencies both deliver more timely and more informative ratings. Xia (2014) finds that the market reaction to rating changes by $\mathrm{S} \& \mathrm{P}$ is greater for bonds that are covered by Egan Jones.

In the last part of the paper we provided further empirical evidence in order to exclude that the decrease in market response to downgrades after 2003 is: 1) driven by smaller stock excess returns in our sample with respect to the relevant stock market index also in days in which no rating change occurs; or 2) peculiar to downgrades and not holding for other rating actions (upgrades) which would suggest that the decrease is due to less risk aversion or to positive market sentiment.

Summarizing, we find empirical evidence of a reduction in abnormal stock returns associated to downgrades issued by Moody's, S\&P and Fitch, in the short run after the SEC's Report of January 2003. As long as equity abnormal returns measure the information content of ratings, our hypothesis is that the reduction in excess returns that we find after 2003 can be explained by the fact that investors perceive the information conveyed by downgrades as relatively less relevant to their investment decisions with respect to the overall informational environment. The SEC's Report of 2003 did not imply any formal change to the market of ratings; therefore any evidence related to the issue of the Report shall not be a consequence of new regulatory rules. The Report is the result of strong criticisms to Moody's, S\&P and Fitch's behavior especially with the Enron and the WorldCom scandals, and it spurred enough debate and attention on the three rating 
agencies to negatively affect investors' perception of the informative value of ratings. This lead to increasing resort to alternative information that was becoming more available in that period due to the widening of information disclosure imposed on corporate entities and equity analysts by the Sarbanes-Oxley Act, the development of new financial products (such as stock options and CDS) and the general increase of financial information sources due to the development of web based information providers.

Concluding, we think that ratings are still so widely demanded not because of the unique information they convey, but because they possess the value of an easy at hand certification of credit quality. Although investors have reduced their reliance on ratings and the regulator has removed every reference to ratings in financial provisions with the Dodd-Frank Act, they are still widely used in private contracting and as governance tools to solve principal-agents conflicts. Thus, in our opinion ratings still play a relevant role because issuers have incentives to demand them in need of certification (Sufi 2009; Kisgen and Strahan, 2010) and because their use has become an established practice. Survey data confirm our findings, among others the Duff and Eining (2007) survey reports that 54 percent of interviewed investors indicate that rating "[...] was just one input of many". Even more significantly, the survey by Cantor et al. (2007) highlights that herding behavior is as relevant as a motivation for the use of ratings for Fund Managers and Plan Sponsors as the thought that relying on ratings is a good investment strategy.

\section{References}

Allen, A. C., \& Dudney, D. M., 2008. The impact of rating agency reputation on local government bond yields. Journal of Financial Services Research,33(1), 57-76.

Avramov, D., Chordia, T., Jostova, G., Philipov, A., 2009. Credit ratings and the cross-section of stock returns. Journal of Financial Markets 12(3), 469-499.

Baghai, R. P., Servaes, H., Tamayo, A. (2014). Have rating agencies become more conservative? Implications for capital structure and debt pricing. The Journal of Finance 69(5), 1961-2005. 
Bannier, C.E., Hirsch, C.W., 2010. The economic function of credit rating agencies: What does the watch list tell us? Journal of Banking \& Finance 34, 3037-3049.

Becker, B., Milbourn, T., 2011. How did increased competition affect credit ratings? Journal of Financial Economics 101(3), 493-514.

Beaver, W.H., Shakespeare, C., Soliman, M.T., 2006. Differential properties in the ratings of certified versus non-certified bond rating agencies. Journal of Accounting \& Economics 42, 303334.

Bruno, V., Cornaggia, J., Cornaggia, K., forthcoming. Does Regulatory Certification Affect the Information Content of Credit Ratings? Management Science.

Candelon, B., Gautier, A. Petit, N., 2014. Market Power in the Credit Rating Industry: State of Play and Proposal for Reforms. CPI Antitrust Chronicle, January 2014 (2).

Cantor, R., Gwilym, O.A., Thomas, S.H., 2007. The use of credit ratings in investment management in US and Europe. The Journal of Fixed Income 17(2), 13-26.

Carhart, M.M., 1997. On persistence in mutual fund performance. The Journal of Finance 52, $57-$ 82.

Chava, Sudheer and Ganduri, Rohan and Ornthanalai, Chayawat, Are Credit Ratings Still Relevant? (April 5, 2015). EFA 2012, Copenhagen, 15-18 August 2012. Available at SSRN: http://ssrn.com/abstract=2023998 or http://dx.doi.org/10.2139/ssrn.2023998

Cheng, M., Neamtiu, M., 2009. An empirical analysis of changes in credit rating properties: Timeliness, accuracy and volatility. Journal of Accounting and Economics 47, 108-130.

Cornaggia, J., \& Cornaggia, K. J., 2013. Estimating the costs of issuer-paid credit ratings. Review of Financial Studies, 26(9), 2229-2269. 
Corrado, Charles J., 1989. A nonparametric test for abnormal security-price performance in event studies. Journal of Financial Economics 23(2), 385-395.

Dichev, I.D., Piotroski, J.D., 2001. The long-run stock returns following bond ratings changes. The Journal of Finance 56, 173-204.

Dilly, M., Mählmann, T., 2015. Is There a 'Boom Bias' in Agency Ratings?. Review of Finance, $1-33$.

Doherty, N. A., Kartasheva, A., \& Phillips, R. D., 2012. Competition among rating agencies and its impact on information disclosure. Journal of Financial Economics, 106, 308-330.

Duff, A., Eining, S., 2007. Credit Rating Agencies: Meeting the Needs of the Market? The Institute of Chartered Accountants of Scotland, Edinburgh.

Fama, E.F., French, K.R., 1993. Common risk factors in the returns on stocks and bonds. Journal of Financial Economics 33, 3-56.

Flannery, M. J., Houston, J. F., Partnoy, F., 2010. Credit Default Swap Spreads as Viable Substitutes for Credit Ratings. University of Pennsylvania Law Review 158, 2085-2123

Goh, J.C., Ederington, L.H., 1993. Is a bond rating downgrade bad news, good news, or no news for stockholders? The Journal of Finance 48, 2001-2008.

Goh, J.C., Ederington, L.H., 1999. Cross-sectional variation in the stock market reaction to bond rating changes. The Quarterly Review of Economics and Finance 39, 101-112.

Han, S. H., Pagano, M. S., Shin, Y. S., 2012. Rating Agency Reputation, the Global Financial Crisis, and the Cost of Debt. Financial Management 41, 849-884.

Hand, J.R.M., Holthausen, R.W., Leftwich, R.W., 1992. The effect of bond rating agency announcements on bond and stock prices. The Journal of Finance 47, 773-752. 
Hill, C.A., 2009. Why did anyone listen to the Rating Agencies after Enron? Journal of Business and Technology Law 4, 283-294.

Hite, G., Warga, A., 1997. The effect of bond-rating changes on bond price performance. Financial Analysts Journal 53, 35-51.

Holthausen, R.W., Leftwich, R.W., 1986. The effect of bond rating changes on common stock prices. Journal of Financial Economics 17, 57-89.

Hull, J., Predescu, M., White, A., 2004. The relationship between credit default swap spreads, bond yields, and credit rating announcements. Journal of Banking \& Finance 28(11), 2789-2811. Iannotta, G., Nocera, G., Resti, A., 2013. Do investors care about credit ratings? An analysis through the cycle, Journal of Financial Stability 9(4), 545-555.

Jorion, P., Liu, Z., Shi, C., 2005. Informational effects of regulation FD: Evidence from rating agencies. Journal of Financial Economics 76, 309-330.

Jorion, P., Zhang, G., 2007. Information effects of bond rating changes: the role of the rating prior to the announcement. Journal of Fixed Income 16, 45-59.

Kisgen, D. J., Strahan, P. E., 2010. Do regulations based on credit ratings affect a firm's cost of capital?. Review of Financial Studies, 23, 4324-4347.

Kolari, J., Pynnönen, S., 2010. Event Study Testing with Cross-Sectional Correlation of Abnormal Returns, Review of Financial Studies 23, 3996-4025.

Kothari, S. P., and J. B. Warner. "Econometrics of Event Studies. Handbook of Corporate Finance: Empirical Corporate Finance. B. Espen Eckbo." (2007).

Löffler, G., 2004a. An Anatomy of Rating through the Cycle. Journal of Banking \& Finance 28(3), 695-720. 
Löffler, G., 2004b. Ratings versus market-based measures of default risk in portfolio governance. Journal of Banking and Finance 28, 2715-2746.

Löffler, G., 2013a. Can rating agencies look through the cycle? Review of Quantitative Finance and Accounting 40(4), 623-646

Löffler, G., 2013b. Can market discipline work in the case of rating agencies? Some lessons from Moody's stock price. Journal of Financial Services Research, 43(2), 149-174.

Lugo, S., Croce, A., \& Faff, R., 2015. Herding behavior and rating convergence among credit rating agencies: Evidence from the subprime crisis.Review of Finance, 19(4), 1703-1731.

Mählmann, T., 2011. Is there a relationship benefit in credit ratings? Review of Finance 15, 475510 .

MacKinlay, A.C., 1997. Event studies in economics and finance. Journal of Economic Literature 35, 13-39.

Moody's, 2003. Are corporate bond ratings procyclical? Moody's Investors Service Special Comment, October.

Moody's, 2006. Analyzing the tradeoff between ratings accuracy and stability.Moody's Investors Service Special Comment, September.

Norden, L., Weber, M., 2004. Informational efficiency of credit default swap and stock markets: The impact of credit rating announcements. Journal of Banking \& Finance 28(11), 2813-2843.

Partnoy, F., 1999. The Siskel and Ebert of Financial Markets: Two Thumbs Down for the Credit Rating Agencies. Washington University Law Quarterly 77(3), 619-712.

Partnoy, F., 2007. Second-Order Benefits from Standards. Boston College Law Rev. 48, 169-191.

Purda, L.D., 2007. Stock market reaction to anticipated versus surprise rating changes. Journal of Financial Research 30(2), 301-320. 
Qian, X., 2014. Small investor sentiment, differences of opinion and stock overvaluation. Journal of Financial Markets 19, 219-246.

Spatt, C., 2009. Discussion of Ratings Shopping and Asset Complexity: A Theory of Ratings Inflation. Journal of Monetary Economics 56(5), 696-699.

Sufi, A. (2009). The real effects of debt certification: Evidence from the introduction of bank loan ratings. Review of Financial Studies, 22(4), 1659-1691.

White, L., 2010. Hearing on Oversight of the Credit Rating Agencies Post-Dodd-Frank, Before the Subcommittee on Oversight and Investigations, Committee of Financial Services of the US House of Representatives (July).

Xia, H., 2014. Can investor-paid credit rating agencies improve the information quality of issuerpaid rating agencies? Journal of Financial Economics 111(2), 450-468. 
Figure 1 Cumulative abnormal returns around downgrades from 1999 to 2011. CAR is cumulative abnormal return in the three day-window around the downgrade's announcement. The vertical line is placed at the end of January 2003 when the SEC's Report is published. The red line represents maximum (maxpre) and minimum (minpre) CAR before January 2003 and the green line represents maximum (maxpost) and minimum (minpost) CAR after January 2003.

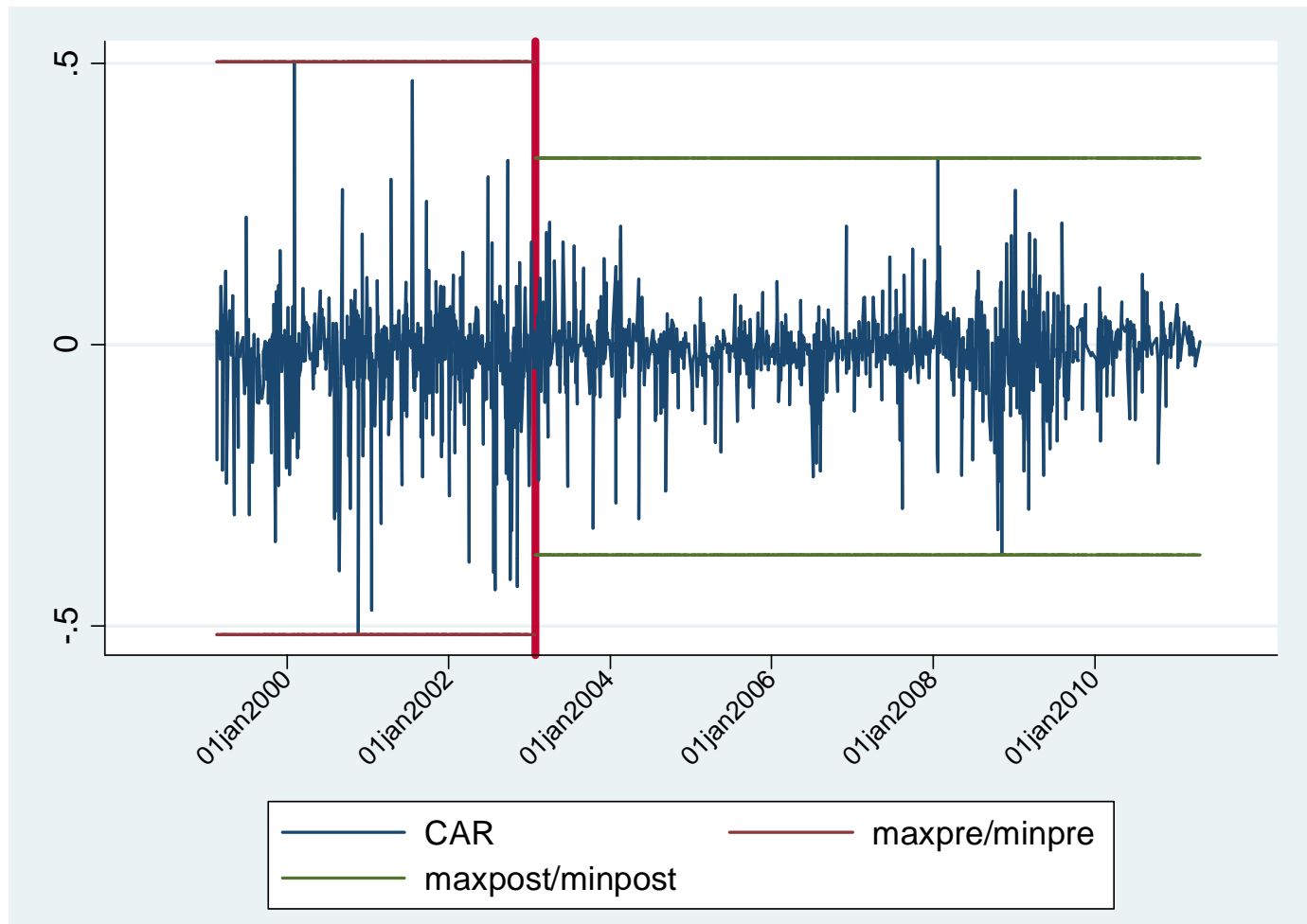


Figure 2 Three months average of cumulative abnormal returns around downgrades from 1999 to 2011. TrimCAR is the average over three months of cumulative abnormal returns in the three day-window around the downgrade's announcement. Several events regarding the rating business are signaled on the on the $\mathrm{x}$-axis. The green line is the average CAR on the whole sample. The vertical line is placed at the end of January 2003 when the SEC's Report is published. The red line represents the average CAR observed before January 2003 and the average CAR observed after January 2003.

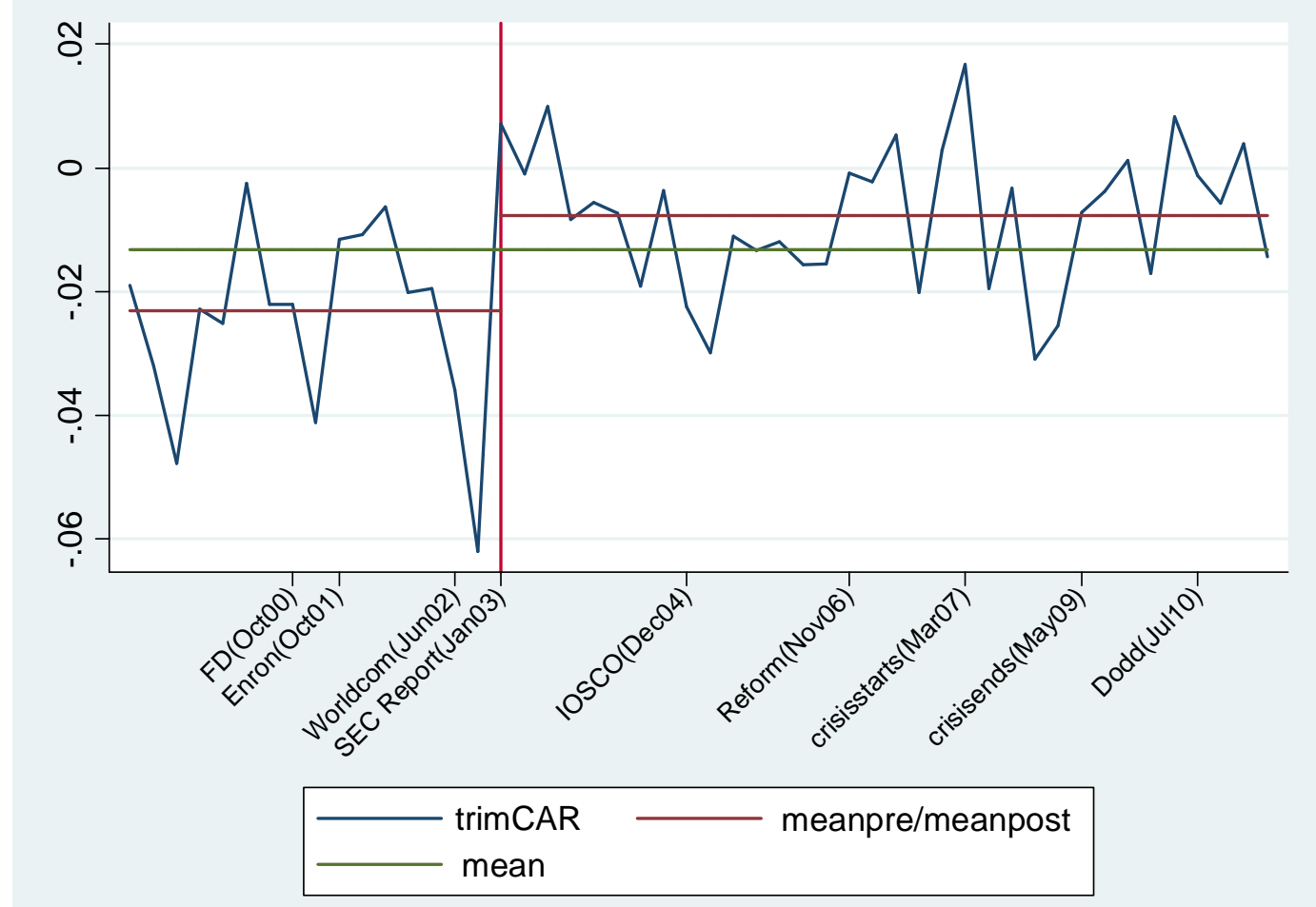


Table 1. Parametric and non-parametric tests on the significance of abnormal returns and cumulative abnormal returns around downgrades. The sample consists of 3023 downgrades of corporate bonds of US firms issued by Moody's, S\&P and Fitch from February 1999 to April 2011. Abnormal returns AR(j) are calculated as in equation [2], estimated using the market model given in equation [1] for a 6 month estimation window; CAR $(-\mathrm{j}, \mathrm{k})$ is the sum of the abnormal returns from $-\mathrm{j}$ to $\mathrm{k}$, where $\mathrm{k}, \mathrm{j}=0$ indicate the event date, the event window starts two days before the event and ends two days after the event. t-test is the standard t-student test. The null hypothesis of sign-rank test is that negative and positive C(AR)s have the same mean rank when ordered basing on their absolute value. The Corrado rank test assumes, under the null hypothesis, that there is equal distribution in the distance of ranked ARs from median rank. The GRANK-Z (Kolari and Pynnönen, 2010) has the same null hypothesis of the Corrado test but is especially devised for CARs.

\begin{tabular}{|c|c|c|c|c|c|c|c|c|c|c|}
\hline \multicolumn{11}{|c|}{ Whole sample statistics } \\
\hline & obs. & Mean & $\begin{array}{l}\text { Media } \\
\mathrm{n}\end{array}$ & $\mathrm{Sd}$ & $\begin{array}{l}\text { Skewnes } \\
\mathrm{s}\end{array}$ & $\begin{array}{l}\text { Kurtosi } \\
\text { s }\end{array}$ & t-statistic & $\begin{array}{l}\text { Sign- } \\
\text { rank-test }\end{array}$ & Corrado & $\begin{array}{l}\text { GRANK- } \\
\mathrm{Z}\end{array}$ \\
\hline & 302 & - & - & 0.053 & & & & - & - & \\
\hline $\mathrm{AR}(-2)$ & $\begin{array}{l}3 \\
302\end{array}$ & $\begin{array}{l}0.0037 \\
-\end{array}$ & $\begin{array}{l}0.0013 \\
-\end{array}$ & $\begin{array}{l}9 \\
0.063\end{array}$ & -3.5099 & 39.6844 & $\begin{array}{l}-3.8 * * * \\
-\end{array}$ & $2.977 * * *$ & $2.992 * * *$ & $-2.91 * * *$ \\
\hline $\mathrm{AR}(-1)$ & $\begin{array}{l}3 \\
302\end{array}$ & $\begin{array}{l}0.0047 \\
-\end{array}$ & $\begin{array}{l}0.0011 \\
-\end{array}$ & $\begin{array}{l}8 \\
0.068\end{array}$ & -2.3957 & 49.2437 & $\begin{array}{l}4.017 * * * \\
-\end{array}$ & $-2.568 * *$ & $\begin{array}{l}-2.232 * * \\
-\end{array}$ & $-2.135 * *$ \\
\hline $\mathrm{AR}(0)$ & $\begin{array}{l}3 \\
302\end{array}$ & 0.0057 & $\begin{array}{l}0.0016 \\
-\end{array}$ & $\begin{array}{l}7 \\
0.056\end{array}$ & 351 & 26.7646 & $\begin{array}{l}4.603 * * * \\
-\end{array}$ & $\begin{array}{l}-4.77 * * * \\
-\end{array}$ & $\begin{array}{l}4.686^{* * *} \\
-\end{array}$ & $-4.823 * * *$ \\
\hline $\mathrm{AR}(+1)$ & $\begin{array}{l}2 \\
300\end{array}$ & -0.005 & $\begin{array}{l}0.0024 \\
-\end{array}$ & $\begin{array}{l}8 \\
0.052\end{array}$ & 0.2005 & 70.4918 & $4.864 * * *$ & $6.997 * * *$ & $6.056 * * *$ & $-6.692 * * *$ \\
\hline $\mathrm{AR}(+2)$ & $\begin{array}{l}7 \\
302\end{array}$ & $\begin{array}{l}0.0004 \\
-\end{array}$ & $\begin{array}{l}0.0006 \\
-\end{array}$ & $\begin{array}{l}6 \\
0.114\end{array}$ & 3.0519 & 64.1792 & $\begin{array}{l}0.377 \\
-\end{array}$ & $\begin{array}{l}-2.198 * * \\
-\end{array}$ & $\begin{array}{l}-2.029 * * \\
-\end{array}$ & $-1.94 *$ \\
\hline $\mathrm{CAR}(-2,0)$ & $\begin{array}{l}3 \\
302\end{array}$ & $\begin{array}{l}0.0141 \\
-\end{array}$ & $\begin{array}{l}0.0036 \\
-\end{array}$ & $\begin{array}{l}4 \\
0.097\end{array}$ & -1.3353 & 24.3508 & $\begin{array}{l}6.796 * * * \\
-\end{array}$ & $\begin{array}{l}5.661 * * * \\
-\end{array}$ & $\begin{array}{l}4.986^{* * * *} \\
-\end{array}$ & $-4.773 * * *$ \\
\hline $\operatorname{CAR}(-1,0)$ & $\begin{array}{l}3 \\
302\end{array}$ & $\begin{array}{l}0.0104 \\
-\end{array}$ & $\begin{array}{l}0.0031 \\
-\end{array}$ & $\begin{array}{l}2 \\
0.090\end{array}$ & -0.7621 & 30.2923 & $\begin{array}{l}5.889 * * * \\
-\end{array}$ & $\begin{array}{l}5.656^{* * * *} \\
-\end{array}$ & $\begin{array}{l}5.371 * * * \\
-\end{array}$ & $-4.451 * * *$ \\
\hline $\operatorname{CAR}(0,+1)$ & $\begin{array}{l}2 \\
300\end{array}$ & $\begin{array}{l}0.0108 \\
-\end{array}$ & $\begin{array}{l}0.0041 \\
-\end{array}$ & $\begin{array}{l}7 \\
0.104\end{array}$ & -0.9472 & 26.8352 & $6.536 * * *$ & $\begin{array}{l}7.702 * * * \\
-\end{array}$ & $\begin{array}{l}6.873^{* * *} \\
-\end{array}$ & $-6.738 * * *$ \\
\hline $\begin{array}{l}\operatorname{CAR}(0,+2) \\
\operatorname{CAR}(-\end{array}$ & $\begin{array}{l}7 \\
302\end{array}$ & $\begin{array}{l}0.0104 \\
-\end{array}$ & $\begin{array}{l}0.0045 \\
-\end{array}$ & $\begin{array}{l}7 \\
0.111\end{array}$ & 0.1394 & 27.066 & $\begin{array}{l}5.468 * * * \\
-\end{array}$ & $\begin{array}{l}7.317 * * * \\
-\end{array}$ & $\begin{array}{l}6.196 * * * \\
-\end{array}$ & $-6.561 * * *$ \\
\hline $1,+1)$ & 2 & 0.0155 & 0.0051 & 6 & -1.051 & 25.1318 & $7.614 * * *$ & $8.061 * * *$ & $6.566 * * *$ & $-6.952 * * *$ \\
\hline
\end{tabular}




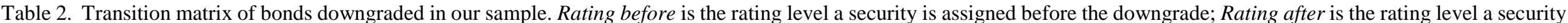

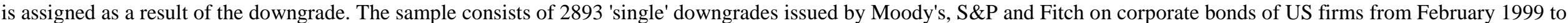
April 2011

Rating after

$\mathrm{AA}+\mathrm{AA}$ AA- $\mathrm{A}+\mathrm{A}$ A- $\mathrm{BBB}+$ BBB $\mathrm{BBB}-\mathrm{BB}+$

BB BB-

$\mathrm{B}+\quad \mathrm{B}$

B-

$\mathrm{CCC}+\mathrm{CCC}$

CCC-

CC $\mathrm{C}$ D

Rating before

AAA

$\mathrm{AA}+$

AA

AA-

$\mathrm{A}+$

A

A-

$\mathrm{BBB}+$

BBB

BBB-

$\mathrm{BB}+$

BB

BB-

$\mathrm{B}+$

B

B-

$\mathrm{CCC}+$

$\mathrm{CCC}$

CCC-

$\mathrm{CC}$

C
$3 \quad 5$

$$
3
$$

$\begin{array}{lll}21 & 4 & 5\end{array}$

$\begin{array}{llll}41 & 14 & 4 & 2\end{array}$

$97 \quad 26 \quad 8$

$160 \quad 32$

169

56

$$
246
$$$$
271 \quad 39
$$$$
39
$$

162

67
93

93

$\begin{array}{ll}67 & 25 \\ 9 & 50\end{array}$

$$
\text { . }
$$

3

26

$\begin{array}{llll}46 & 120 & 191 & 211\end{array}$

$322 \quad 339 \quad 214$

174

$\begin{array}{ll} & \\ & \\ & \\ & \\ & \\ 1 & \\ 1 & \\ 3 & 3 \\ 6 & 5 \\ 25 & 6 \\ 50 & 17 \\ 101 & 46 \\ & 141\end{array}$

$\begin{array}{llll} & & & \\ & & & \\ & & & \\ & & & \\ & & & \\ & 1 & & \\ 4 & 1 & & \\ 6 & 2 & 5 & 2 \\ 19 & 6 & 1 & \\ 48 & 19 & 9 & 1 \\ 129 & 50 & 16 & 4 \\ & 148 & 36 & 12 \\ & & 83 & 36 \\ & & & 52\end{array}$

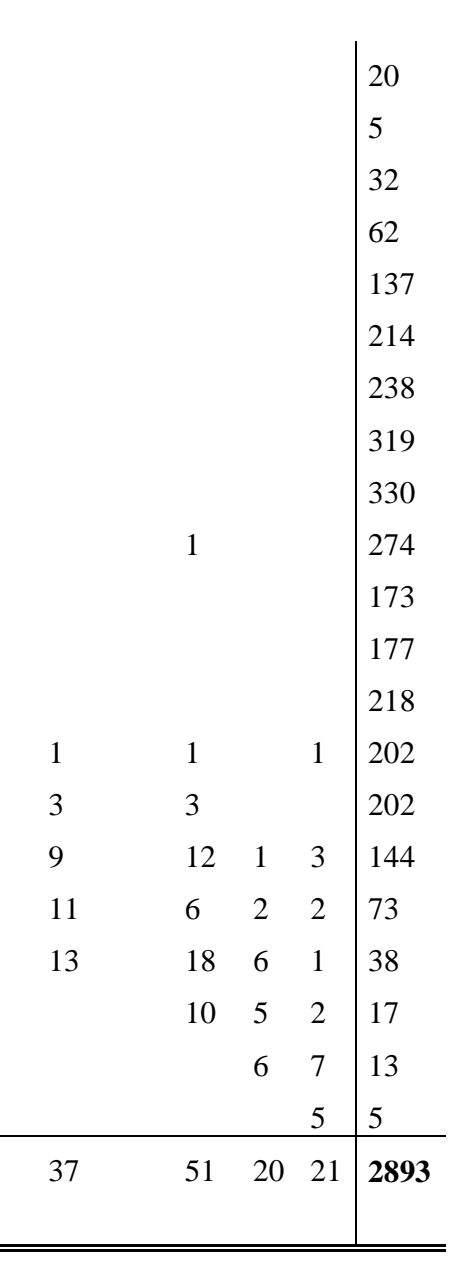


Table 3. Descriptive statistics of variables. The sample consists of 2893 Moody's, S\&P and Fitch's downgrades of US corporate bonds from February 1999 to April 2011. When on the same date two or all credit rating agencies announce a downgrade regarding the same firm, the observation is excluded from the sample. $A R(0)$ is the stock abnormal return of firm $i$ on the day a downgrade is announced for a bond issued by firm $i$. CAR($1,1)$ is the sum of stock abnormal returns on the day of the announcement, the day before and the day after. rchange is the absolute magnitude of the downgrade (number of notches); days equals the number of days elapsing between two downgrades referring to the same firm; employees is the number of employees in the year before the downgrade; dividend yield for each firm refers to six trading days before the downgrade; debt to equity is the ratio of total debt to equity and refers to the year before the downgrade; roe is the return on equity one year before the downgrade; negative watch is a dummy equal to 1 if the downgrade is preceded by a negative watch; threshold is a dummy equal to one if as a consequence of the downgrade a firm's security is revised from investment to speculative grade; investment grade is a dummy equal to 1 if the downgraded security was deemed investment grade before the downgrade. Industry dummies are based on the first 3 digits of NAICS' codes.

\begin{tabular}{|c|c|c|c|c|c|c|}
\hline \multicolumn{7}{|l|}{ Whole sample statistics } \\
\hline & $\mathrm{N}$ & mean & median & $\mathrm{sd}$ & skewness & kurtosis \\
\hline $\mathrm{AR}(0)$ & 2893 & -0.0052 & -0.0015 & 0.07 & -0.98 & 28.47 \\
\hline $\operatorname{CAR}(-1,1)$ & 2892 & -0.0144 & -0.0051 & 0.11 & -0.9 & 26.33 \\
\hline rchange & 2893 & 1.56 & 1 & 1.09 & 3.22 & 17.61 \\
\hline negative watch & 2893 & 0.28 & 0 & 0.45 & 1 & 2.01 \\
\hline threshold & 2893 & 0.13 & 0 & 0.33 & 2.25 & 6.05 \\
\hline investment grade & 2893 & 0.56 & 1 & 0.5 & -0.26 & 1.07 \\
\hline days & 2893 & 631 & 173 & 1118 & 3.2 & 15.35 \\
\hline employees & 2707 & 37258 & 12800 & 62743 & 3.35 & 16.12 \\
\hline dividend yield & 2893 & 2.29 & 1.24 & 3.44 & 4.6 & 43.55 \\
\hline debt to equity & 2606 & -0.3 & 1.09 & 23.18 & -13.79 & 226.64 \\
\hline roe & 2558 & -0.09 & 0.06 & 1.56 & -17.48 & 499.45 \\
\hline \multicolumn{7}{|l|}{ Industry dummies: } \\
\hline Auto \& Parts & 2893 & 0.04 & 0 & 0.19 & 4.99 & 25.85 \\
\hline Basic Resource & 2893 & 0.05 & 0 & 0.22 & 4.14 & 18.14 \\
\hline Chemicals & 2893 & 0.05 & 0 & 0.22 & 4.01 & 17.09 \\
\hline Construction \& Materials & 2893 & 0.03 & 0 & 0.18 & 5.24 & 28.49 \\
\hline Food\&Bev. & 2893 & 0.03 & 0 & 0.18 & 5.1 & 26.97 \\
\hline $\begin{array}{l}\text { Health Care } \\
\text { Industrial Goods }\end{array}$ & 2893 & 0.05 & 0 & 0.22 & 4.04 & 17.34 \\
\hline Services & 2893 & 0.12 & 0 & 0.33 & 2.29 & 6.27 \\
\hline Media & 2893 & 0.06 & 0 & 0.23 & 3.89 & 16.14 \\
\hline Oil\&Gas & 2893 & 0.07 & 0 & 0.26 & 3.24 & 11.47 \\
\hline Pers \& H/H Gds & 2893 & 0.1 & 0 & 0.31 & 2.59 & 7.73 \\
\hline Real Estate & 2893 & 0.01 & 0 & 0.1 & 9.84 & 97.77 \\
\hline Retail & 2893 & 0.12 & 0 & 0.32 & 2.41 & 6.82 \\
\hline Technology & 2893 & 0.04 & 0 & 0.2 & 4.69 & 22.98 \\
\hline Tlc & 2893 & 0.06 & 0 & 0.23 & 3.83 & 15.7 \\
\hline Travel \& Leisure & 2893 & 0.06 & 0 & 0.23 & 3.86 & 15.92 \\
\hline Utilities & 2893 & 0.11 & 0 & 0.31 & 2.58 & 7.63 \\
\hline
\end{tabular}


Table 4. Comparison of the main downgrades' characteristics before and after the SEC's Report issued on January 24, 2003. The sample consists of 2893 corporate bond downgrades issued by Moody's, S\&P and Fitch from February 1999 to April 2011. The pre-SEC's Report period ends on January 23, 2003; the post-SEC's Report period starts on January 24, 2003. rchange is the absolute magnitude of the downgrade (number of notches); days equals the number of days elapsing between two downgrades referring to the same firm; negative watch is a dummy variable equal to 1 when the downgrade is preceded by a negative watch; threshold is a binary variable equal to one if as a consequence of the downgrade a firm's security is revised from investment grade to speculative grade; investment grade is a dummy equal to 1 if the downgraded security was deemed investment grade before the downgrade.

\begin{tabular}{|c|c|c|c|c|c|c|c|c|c|}
\hline & \multicolumn{4}{|c|}{ PRE SEC REPORT 2003} & \multicolumn{4}{|c|}{ POST SEC REPORT 2003} & \multirow{2}{*}{$\begin{array}{l}\text { t-test } \\
\text { |Diff. in means| }\end{array}$} \\
\hline & $\mathrm{N}$ & mean & median & $\mathrm{sd}$ & $\mathrm{N}$ & mean & median & sd & \\
\hline rchange & 1059 & 1.569 & 1 & 1,029 & 1834 & 1.549 & 1 & 1,117 & 0.021 \\
\hline days & 1059 & 621 & 147 & 1161 & 1834 & 636 & 185 & 1093 & 15 \\
\hline negative watch & 1059 & 0.15 & 0 & 0.356 & 1834 & 0.35 & 0 & 0.477 & $0.2 * * *$ \\
\hline threshold & 1059 & 0.132 & 0 & 0.339 & 1834 & 0.123 & 0 & 0.329 & 0.009 \\
\hline $\begin{array}{l}\text { investment } \\
\text { grade }\end{array}$ & 1059 & 0.671 & 1 & 0.47 & 1834 & 0.502 & 1 & 0.5 & $0.17 * * *$ \\
\hline
\end{tabular}




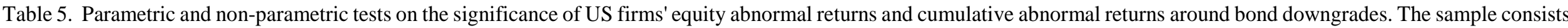

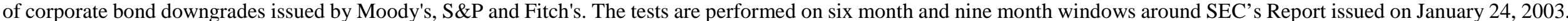

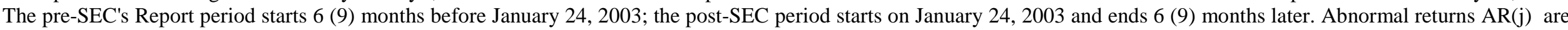

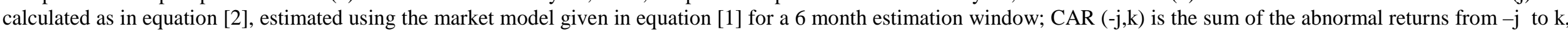

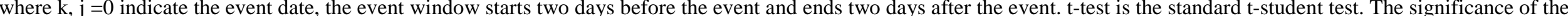

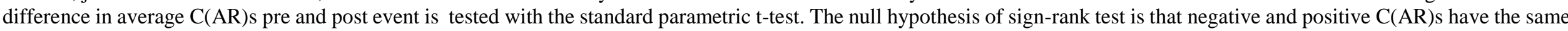

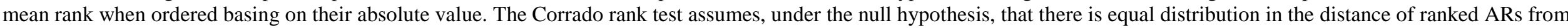
median rank. The GRANK-Z (Kolari and Pynnönen, 2010) has the same null hypothesis of the Corrado test but is especially devised for CARs.

\begin{tabular}{|c|c|c|c|c|c|c|c|c|c|c|c|}
\hline & \multicolumn{5}{|c|}{ PRE SEC REPORT 2003} & \multicolumn{5}{|c|}{ POST SEC REPORT 2003} & \multirow{2}{*}{$\begin{array}{l}\text { t-test } \\
\mid \text { Diff. in means } \mid\end{array}$} \\
\hline & $\mathrm{N}$ & Mean & t-statistic & sign-rank & GRANK-Z & $\mathrm{N}$ & Mean & t-statistic & sign-rank & GRANK-Z & \\
\hline \multicolumn{12}{|c|}{6 month window } \\
\hline $\mathrm{AR}(0)$ & 178 & -0.021 & $-2.603 * * *$ & $-3.296 * * *$ & $-3.14 * * *$ & 138 & 0.002 & 0.3 & 0.104 & -1.2 & $0.023 * *$ \\
\hline $\operatorname{CAR}(-1,+1)$ & 178 & -0.048 & $-3.026^{* * *}$ & $-5.154 * * *$ & $-4.007 * * *$ & 138 & 0.005 & 0.383 & -1.064 & 0.527 & $0.053 * * *$ \\
\hline \multicolumn{12}{|c|}{9 month window } \\
\hline $\mathrm{AR}(0)$ & 265 & -0.016 & $-2.79 * * *$ & $-2.88 * * *$ & $-4.622 * * *$ & 197 & -0.001 & -0.214 & $-1.921 *$ & $-1.9^{*}$ & $0.015^{* *}$ \\
\hline $\operatorname{CAR}(-1,+1)$ & 265 & -0.037 & $-3.313 * * *$ & $-4.363 * * *$ & $-5.100 * * *$ & 197 & -0.002 & -0.192 & -0.477 & -0.132 & $0.035 * *$ \\
\hline
\end{tabular}


Table 6. Comparison of the main downgrades' characteristics before and after the SEC's Report issued on January 24 , 2003. The sample consists of corporate bond downgrades issued by Moody's, S\&P and Fitch. The pre-SEC's Report period starts 6 (9) months before January 24, 2003; the post-SEC period starts on January 24, 2003 and ends 6 (9) months later. rchange is the absolute magnitude of the downgrade (number of notches); days equals the number of days elapsing between two downgrades referring to the same firm; negative watch is a dummy variable equal to 1 when the downgrade is preceded by a negative watch; threshold is a binary variable equal to one if as a consequence of the downgrade a firm's security is revised from investment grade to speculative grade; investment grade is a dummy equal to 1 if the downgraded security was deemed investment grade before the downgrade.

\begin{tabular}{|c|c|c|c|c|c|c|c|c|c|}
\hline & \multicolumn{4}{|c|}{ PRE SEC REPORT 2003} & \multicolumn{4}{|c|}{ POST SEC REPORT 2003} & \multirow{2}{*}{$\begin{array}{l}\text { t-test } \\
\text { |Diff. in means }\end{array}$} \\
\hline & $\mathrm{N}$ & mean & median & sd & $\mathrm{N}$ & mean & median & sd & \\
\hline \multicolumn{10}{|l|}{ month } \\
\hline window & & & & & & & & & \\
\hline rchange & 178 & 1.556 & 1 & 0.795 & 138 & 1.594 & 1 & 1.071 & 0.038 \\
\hline days & 178 & 426 & 106 & 925 & 138 & 353 & 102 & 829 & 73.03 \\
\hline negative watch & 178 & 0.449 & 0 & 0.499 & 138 & 0.413 & 0 & 0.494 & 0.036 \\
\hline threshold & 178 & 0.14 & 0 & 0.348 & 138 & 0.145 & 0 & 0.353 & 0.005 \\
\hline $\begin{array}{l}\text { investment } \\
\text { grade }\end{array}$ & 178 & 0.584 & 1 & 0.494 & 138 & 0.587 & 1 & 0.494 & 0.003 \\
\hline \multicolumn{10}{|l|}{9 month } \\
\hline window & & & & & & & & & \\
\hline rchange & 265 & 1.54 & 1 & 0,788 & 197 & 1.533 & 1 & 0.998 & 0.007 \\
\hline days & 265 & 403 & 104 & 873 & 197 & 399 & 131 & 834 & 3.887 \\
\hline negative watch & 265 & 0.468 & 0 & 0.5 & 197 & 0.391 & 0 & 0.489 & $0.077 * *$ \\
\hline threshold & 265 & 0.14 & 0 & 0.347 & 197 & 0.132 & 0 & 0.339 & 0.008 \\
\hline $\begin{array}{l}\text { investment } \\
\text { grade }\end{array}$ & 265 & 0.577 & 1 & 0.495 & 197 & 0.548 & 1 & 0.499 & 0.029 \\
\hline
\end{tabular}

Table 7. Parametric tests on the significance of abnormal returns and cumulative abnormal returns around bond downgrades which are not preceded by a credit watch. The sample consists of corporate bond downgrades issued by Moody's, S\&P and Fitch. The tests are performed on 6 month and 9 month windows around SEC's Report issued on January 24, 2003. The pre-SEC's Report period starts 6 (9) months before January 24, 2003; the post-SEC period starts on January 24, 2003 and ends 6 (9) months later. Abnormal returns AR(j) are calculated as in equation [2], estimated using the market model given in equation [1] for a 6 month estimation window; CAR $(-\mathrm{j}, \mathrm{k})$ is the sum of the abnormal returns from $-\mathrm{j}$ to $\mathrm{k}$, where $\mathrm{k}, \mathrm{j}=0$ indicate the event date. The event window starts two days before the event and ends two days after the event. $t$-test is the standard t-student test. The significance of the difference in average $C(A R) s$ pre and post event is tested with the standard parametric t-test.

\section{PRE SEC REPORT $2003 \quad$ POST SEC REPORT 2003}

$\underline{N}$ Mean t-statistic $\quad$ N Mean t-statistic $\quad$ t-test |Diff. in means|

\section{6 month window}

$\begin{array}{llllllll}\operatorname{AR}(0) & 98 & -0.033 & -2.64 * * * & 81 & 0.007 & 1.19 & 0.04 * * * \\ \operatorname{CAR}(-1,+1) & 98 & -0.084 & -3.913 * * * & 81 & 0.007 & 0.7 & 0.09 * * *\end{array}$

\section{9 month window}

$\begin{array}{llllllll}\operatorname{AR}(0) & 141 & -0.027 & -3.017 * * * & 120 & 0.003 & 0.78 & 0.03 * * * \\ \mathrm{CAR}(-1,+1) & 141 & -0.064 & -4.154^{* * *} & 120 & 0.002 & 0.208 & 0.066^{* * *}\end{array}$


Table 8. Determinants of CARs around downgrades. The dependent variable is the cumulative abnormal return computed over a three day event window CAR $(-1,+1)$. rchange is the absolute magnitude of the downgrade (number of notches); negative watch is a dummy variable equal to 1 when the downgrade is preceded by a negative watch; investment grade is a dummy equal to 1 if the downgraded security was deemed investment grade before the downgrade, threshold is a binary variable equal to one if as a consequence of the downgrade a firm's security is revised from investment grade to speculative grade; days equals the logarithm of the number of days elapsing between two downgrades referring to the same firm; crisis01 and crisis07 are dummies equal to 1 in the months in which the crises occur ; debt to equity, roe, log(employees) and dividend yield are controls for firms' lagged characteristics; we further control for industry and rating agency common effects. (Robust standard errors). *** indicate significance at the $1 \%$ level $* *$ at the $5 \%$ and $*$ at the $10 \%$.

\begin{tabular}{|c|c|c|c|c|c|}
\hline & (1) & (2) & (3) & (4) & (5) \\
\hline \multirow[t]{2}{*}{ rchange } & $-0.0048^{*}$ & $-0.0061 * *$ & $-0.0060 * *$ & $-0.0060 * *$ & $-0.0060 * *$ \\
\hline & $(0.003)$ & $(0.003)$ & $(0.003)$ & $(0.003)$ & $(0.003)$ \\
\hline \multirow[t]{2}{*}{ negative watch } & $0.0134 * * *$ & $0.0147 * * *$ & $0.0158 * * *$ & $0.0159 * * *$ & $0.0159 * * *$ \\
\hline & $(0.005)$ & $(0.005)$ & $(0.005)$ & $(0.005)$ & $(0.005)$ \\
\hline \multirow[t]{2}{*}{ investment grade } & $0.0135^{* * *}$ & $0.0128 * * *$ & $0.0132 * * *$ & $0.0139 * *$ & $0.0139 *$ \\
\hline & $(0.004)$ & $(0.005)$ & $(0.005)$ & $(0.005)$ & $(0.007)$ \\
\hline \multirow[t]{2}{*}{ threshold } & $-0.0196 * * *$ & $-0.0217 * * *$ & $-0.0222 * * *$ & $-0.0225^{* * *}$ & $-0.0225 * * *$ \\
\hline & $(0.007)$ & $(0.007)$ & $(0.007)$ & $(0.007)$ & $(0.008)$ \\
\hline \multirow[t]{2}{*}{ days } & $0.0019 *$ & $0.0022 *$ & $0.0021 *$ & $0.0020 *$ & $0.0020 *$ \\
\hline & $(0.001)$ & $(0.001)$ & $(0.001)$ & $(0.001)$ & $(0.001)$ \\
\hline \multirow{2}{*}{ debt to equity } & & $-0.0002 * *$ & $-0.0002 * *$ & $-0.0002 * *$ & $-0.0002 * *$ \\
\hline & & $(0.000)$ & $(0.000)$ & $(0.000)$ & $(0.000)$ \\
\hline \multirow[t]{2}{*}{ roe } & & & $-0.0028 * *$ & $-0.0028 * *$ & $-0.0028 * *$ \\
\hline & & & $(0.001)$ & $(0.001)$ & $(0.001)$ \\
\hline \multirow{2}{*}{$\log ($ employees $)$} & & & & -0.0005 & -0.0005 \\
\hline & & & & $(0.002)$ & $(0.002)$ \\
\hline \multirow[t]{2}{*}{ dividend yield } & & & & & -0.0001 \\
\hline & & & & & $(0.003)$ \\
\hline \multirow[t]{2}{*}{ crisis01 } & 0.0063 & $0.0135^{*}$ & 0.0122 & 0.0123 & 0.0122 \\
\hline & $(0.007)$ & $(0.007)$ & $(0.008)$ & $(0.008)$ & $(0.008)$ \\
\hline \multirow[t]{2}{*}{ crisis07 } & 0.0040 & 0.0039 & 0.0009 & 0.0009 & 0.0010 \\
\hline & $(0.006)$ & $(0.006)$ & $(0.006)$ & $(0.006)$ & $(0.007)$ \\
\hline \multirow[t]{2}{*}{ Constant } & $-0.0197 *$ & -0.0179 & -0.0200 & -0.0109 & -0.0109 \\
\hline & $(0.012)$ & $(0.012)$ & $(0.016)$ & $(0.021)$ & $(0.021)$ \\
\hline Observations & 2,892 & 2,606 & 2,458 & 2,455 & 2,455 \\
\hline Industry dummies & Yes & Yes & Yes & Yes & Yes \\
\hline Agency dummies & Yes & Yes & Yes & Yes & Yes \\
\hline Adj. R-squared & 0.0107 & 0.0141 & 0.0178 & 0.0174 & 0.0170 \\
\hline $\mathrm{F}$ & 2.080 & 2.185 & 2.313 & 2.234 & 2.156 \\
\hline
\end{tabular}


Table 9. Determinants of CARs around downgrades. The dependent variable is the cumulative abnormal return computed over a three day event window CAR(-1, +1). sec is a dummy equal to 1 as of January 24, 2003, when the SEC's Report is issued. rchange is the absolute magnitude of the downgrade (number of notches); negative watch is a dummy variable equal to 1 when the downgrade is preceded by a negative watch; investment grade is a dummy equal to 1 if the downgraded security was deemed investment grade before the downgrade, threshold is a binary variable equal to one if as a consequence of the downgrade a firm's security is revised from investment grade to speculative grade; days equals the logarithm of the number of days elapsing between two downgrades referring to the same firm; crisis01 and crisis07 are dummies equal to 1 in the months in which the crises occur ; debt to equity, roe, $\log$ (employees) and dividend yield are controls for firms' lagged characteristics; we further control for industry and rating agency (Fitch, Moody's, S\&P) common effects. In column 2 we add $f d$, enron, reform06 and dodd-frank that are dummies set equal to 1 as of each event occurrence (10/2000, 10/2001, 09/2006 and 07/2010 respectively) used as controls for other events affecting the rating business. In column 3 we drop downgrades issued after September 29, 2006 to exclude possibly confounding events taking place after SEC's Report. In column 4 and 5 we split the sample in pre and post SEC's Report. (Robust standard errors). *** indicate significance at the $1 \%$ level $* *$ at the $5 \%$ and $*$ at the $10 \%$.

\begin{tabular}{|c|c|c|c|c|c|}
\hline & \multicolumn{2}{|c|}{ Whole sample } & \multirow{2}{*}{$\begin{array}{l}\text { Pre-Reform } 2006 \\
(3)\end{array}$} & \multirow{2}{*}{$\begin{array}{l}\text { Pre-SEC } \\
(4)\end{array}$} & \multirow{2}{*}{$\begin{array}{l}\text { Post-SEC } \\
(5)\end{array}$} \\
\hline & (1) & (2) & & & \\
\hline \multirow[t]{2}{*}{ rchange } & $-0.0057 * *$ & $-0.0058 * *$ & $-0.0080^{*}$ & $-0.0134 *$ & -0.0038 \\
\hline & $(0.003)$ & $(0.003)$ & $(0.004)$ & $(0.008)$ & $(0.002)$ \\
\hline \multirow[t]{2}{*}{$\sec$} & $0.0170 * * *$ & $0.0213 * * *$ & $0.0181 * * *$ & & \\
\hline & $(0.006)$ & $(0.008)$ & $(0.006)$ & & \\
\hline \multirow[t]{2}{*}{ negative watch } & $0.0130 * * *$ & $0.0151 * * *$ & $0.0153 * *$ & $0.0394 * *$ & 0.0052 \\
\hline & $(0.005)$ & $(0.005)$ & $(0.007)$ & $(0.016)$ & $(0.004)$ \\
\hline \multirow[t]{2}{*}{ investment grade } & $0.0161 * *$ & $0.0153 * *$ & 0.0152 & 0.0168 & $0.0138 * * *$ \\
\hline & $(0.007)$ & $(0.007)$ & $(0.011)$ & $(0.016)$ & $(0.005)$ \\
\hline \multirow[t]{2}{*}{ threshold } & $-0.0230 * * *$ & $-0.0225 * * *$ & $-0.0265^{* *}$ & $-0.0408 * *$ & $-0.0113^{*}$ \\
\hline & $(0.008)$ & $(0.008)$ & $(0.010)$ & $(0.017)$ & $(0.006)$ \\
\hline \multirow[t]{2}{*}{ days } & $0.0018^{*}$ & 0.0017 & $0.0025^{*}$ & 0.0033 & 0.0010 \\
\hline & $(0.001)$ & $(0.001)$ & $(0.001)$ & $(0.002)$ & $(0.001)$ \\
\hline \multirow[t]{2}{*}{ debt to equity } & $-0.0002 * *$ & $-0.0002 * *$ & $-0.0002 *$ & -0.0001 & $-0.0003 * *$ \\
\hline & $(0.000)$ & $(0.000)$ & $(0.000)$ & $(0.000)$ & $(0.000)$ \\
\hline \multirow[t]{2}{*}{ roe } & $-0.0027 * *$ & $-0.0028 * *$ & 0.0004 & 0.0045 & $-0.0033 * * *$ \\
\hline & $(0.001)$ & $(0.001)$ & $(0.003)$ & $(0.003)$ & $(0.001)$ \\
\hline \multirow[t]{2}{*}{$\log$ (employees) } & -0.0005 & -0.0004 & -0.0005 & -0.0017 & -0.0002 \\
\hline & $(0.002)$ & $(0.002)$ & $(0.002)$ & $(0.004)$ & $(0.002)$ \\
\hline \multirow[t]{2}{*}{ dividend yield } & 0.0002 & 0.0001 & 0.0021 & 0.0020 & -0.0009 \\
\hline & $(0.003)$ & $(0.003)$ & $(0.005)$ & $(0.007)$ & $(0.001)$ \\
\hline \multirow[t]{2}{*}{ crisis01 } & $0.0216^{* *}$ & 0.0201 & $0.0225 * * *$ & $0.0230 * *$ & \\
\hline & $(0.008)$ & $(0.013)$ & $(0.009)$ & $(0.009)$ & \\
\hline \multirow[t]{2}{*}{ crisis07 } & -0.0047 & -0.0037 & & & -0.0031 \\
\hline & $(0.006)$ & $(0.007)$ & & & $(0.006)$ \\
\hline \multirow[t]{2}{*}{$\mathrm{fd}$} & & -0.0036 & & & \\
\hline & & $(0.014)$ & & & \\
\hline \multirow[t]{2}{*}{ enron } & & -0.0085 & & & \\
\hline & & $(0.014)$ & & & \\
\hline \multirow[t]{2}{*}{ reform 06} & & 0.0001 & & & \\
\hline & & $(0.004)$ & & & \\
\hline \multirow[t]{2}{*}{ dodd-frank } & & $0.0141 * *$ & & & \\
\hline & & $(0.007)$ & & & \\
\hline \multirow[t]{2}{*}{ Constant } & -0.0225 & -0.0156 & -0.0394 & -0.0276 & -0.0110 \\
\hline & $(0.021)$ & $(0.022)$ & $(0.031)$ & $(0.051)$ & $(0.023)$ \\
\hline Observations & 2,455 & 2,455 & 1,548 & 860 & 1,595 \\
\hline Industry dummies & Yes & Yes & Yes & Yes & Yes \\
\hline Agency dummies & Yes & Yes & Yes & Yes & Yes \\
\hline Adj. R-squared & 0.0209 & 0.0205 & 0.0255 & 0.0262 & 0.0156 \\
\hline $\mathrm{F}$ & 2.150 & 2.070 & 2.054 & 1.587 & 1.877 \\
\hline
\end{tabular}


Table 10. Positive and Negative CARs determinants around downgrades. The sample consists of 2893 downgrades issued by Moody's, S\&P and Fitch on corporate bonds of US firms from February 1999 to April 2011. The dependent variable is the cumulative abnormal return computed over a three day event window CAR $(-1,+1)$. Abnormal returns are estimated using the market model in equation [1] for a 6 month estimation window. sec is a dummy equal to 1 as of January 24, 2003 when the SEC's Report is issued. rchange is the absolute magnitude of the downgrade (number of notches). neg is a dummy indicator for $\operatorname{CAR}(-1,+1)<0$. negative watch is a dummy variable equal to 1 when the downgrade is preceded by a negative watch. investment grade is a dummy equal to 1 if the downgraded security was deemed investment grade before the downgrade. threshold is a binary variable equal to one if as a consequence of the downgrade a firm's security is revised from investment grade to speculative grade. days equals the logarithm of the number of days elapsing between two downgrades referring to the same firm. crisis01 and crisis07 are dummies equal to 1 in the months in which the crises occur according to NBER business cycle dates. debt to equity, roe, log(employees) and dividend yield are controls for firms' lagged characteristics. We further control for industry and rating agency (Fitch, Moody's, S\&P) common effects. We analyze separately positive and negative CARs. (Robust standard errors). $* * *$ indicate significance at the $1 \%$ level $* *$ at the $5 \%$ and $*$ at the $10 \%$.

\begin{tabular}{|c|c|c|}
\hline & (1) & (2) \\
\hline & Positive CARs & Negative CARs \\
\hline \multirow[t]{2}{*}{ rchange } & $0.0058 * *$ & $-0.0101 * * *$ \\
\hline & $(0.003)$ & $(0.004)$ \\
\hline \multirow[t]{2}{*}{$\sec$} & $-0.0314 * * *$ & $0.0543 * * *$ \\
\hline & $(0.005)$ & $(0.007)$ \\
\hline \multirow[t]{2}{*}{ negative watch } & $0.0094 * *$ & $0.0096^{*}$ \\
\hline & $(0.005)$ & $(0.005)$ \\
\hline \multirow[t]{2}{*}{ investment grade } & $-0.0388 * * *$ & $0.0512 * * *$ \\
\hline & $(0.009)$ & $(0.007)$ \\
\hline \multirow[t]{2}{*}{ threshold } & 0.0043 & $-0.0273 * * *$ \\
\hline & $(0.005)$ & $(0.010)$ \\
\hline \multirow[t]{2}{*}{ days } & -0.0012 & $0.0033 * * *$ \\
\hline & $(0.001)$ & $(0.001)$ \\
\hline \multirow{2}{*}{ debt to equity } & $-0.0002 *$ & 0.0001 \\
\hline & $(0.000)$ & $(0.000)$ \\
\hline \multirow[t]{2}{*}{ roe } & $-0.0025 * * *$ & 0.0022 \\
\hline & $(0.001)$ & $(0.003)$ \\
\hline \multirow[t]{2}{*}{$\log$ (employees) } & -0.0022 & -0.0023 \\
\hline & $(0.002)$ & $(0.002)$ \\
\hline \multirow[t]{2}{*}{ dividend yield } & 0.0069 & $-0.0040 * *$ \\
\hline & $(0.004)$ & $(0.002)$ \\
\hline \multirow[t]{2}{*}{ crisis01 } & -0.0034 & 0.0173 \\
\hline & $(0.007)$ & $(0.011)$ \\
\hline \multirow[t]{2}{*}{ crisis07 } & $0.0284 * * *$ & $-0.0361 * * *$ \\
\hline & $(0.007)$ & $(0.006)$ \\
\hline \multirow[t]{2}{*}{ Constant } & $0.0932 * * *$ & $-0.1129 * * *$ \\
\hline & $(0.020)$ & $(0.021)$ \\
\hline Observations & 1,089 & 1,366 \\
\hline Industry dummies & Yes & Yes \\
\hline Agency dummies & Yes & Yes \\
\hline Adj. R-squared & 0.181 & 0.159 \\
\hline $\mathrm{F}$ & 6.935 & 11.33 \\
\hline
\end{tabular}

\section{Appendix}


Table A.1. Parametric tests on the significance of US firms' equity cumulative abnormal returns around bond downgrades. The sample consists of corporate bond downgrades issued by Moody's, S\&P and Fitch's. The tests are performed on 18 month windows around the Enron scandal dated October 23, 2001; the WorldCom scandal dated June 28, 2002; the Reform of September 292006 ; the Dodd-Frank Act of July 22, 2010 . The pre period starts 9 months before the event date and ends on the day before event date; the post period starts on the event day and ends 9 months later. CAR $(-1,1)$ is the sum of the abnormal returns on the day before the downgrade, the day of the downgrade and the day after. t-test is the standard t-student test. The significance of the difference in average $\mathrm{C}(\mathrm{AR})$ s pre and post event is tested with the standard parametric t-test.

\begin{tabular}{|c|c|c|c|c|c|c|c|}
\hline & \multicolumn{7}{|c|}{ PANEL A } \\
\hline & \multicolumn{3}{|c|}{ PRE ENRON } & \multicolumn{3}{|c|}{ POST ENRON } & \multirow{2}{*}{$\begin{array}{l}\text { t-test } \\
\text { Diff. in means }\end{array}$} \\
\hline & $\mathrm{N}$ & Mean & $\mathrm{t}$-statistic & $\mathrm{N}$ & Mean & t-statistic & \\
\hline \multicolumn{8}{|c|}{18 month window } \\
\hline \multirow[t]{4}{*}{ CAR $(-1,+1)$} & 224 & -0.013 & $-1.705^{*}$ & 271 & -0.024 & $-2.94 * * *$ & 0.011 \\
\hline & \multicolumn{7}{|c|}{ PANEL B } \\
\hline & \multicolumn{3}{|c|}{ PRE WORLDCOM } & \multicolumn{3}{|c|}{ POST WORLDCOM } & t-test \\
\hline & $\mathrm{N}$ & Mean & $\mathrm{t}$-statistic & $\mathrm{N}$ & Mean & t-statistic & |Diff. in means \\
\hline \multicolumn{8}{|c|}{18 month window } \\
\hline \multirow[t]{4}{*}{ CAR $(-1,+1)$} & 280 & -0.017 & $-2.79 * * *$ & 263 & -0.036 & $-2.9 * * *$ & 0.019 \\
\hline & \multicolumn{7}{|c|}{ PANEL C } \\
\hline & \multicolumn{3}{|c|}{ PRE REFORM 2006} & \multicolumn{3}{|c|}{ POST REFORM 2006} & t-test \\
\hline & $\mathrm{N}$ & Mean & t-statistic & $\mathrm{N}$ & Mean & t-statistic & Diff. in means \\
\hline \multicolumn{8}{|c|}{18 month window } \\
\hline \multirow[t]{4}{*}{ CAR $(-1,+1)$} & 228 & -0.014 & $-4.09 * * *$ & 179 & 0.002 & 0.575 & $0.016^{* * *}$ \\
\hline & \multicolumn{7}{|c|}{ PANEL D } \\
\hline & \multicolumn{3}{|c|}{ PRE DODD-FRANK ACT } & \multicolumn{3}{|c|}{ POST DOOD-FRANK ACT } & t-test \\
\hline & $\mathrm{N}$ & Mean & $\mathrm{t}$-statistic & $\mathrm{N}$ & Mean & t-statistic & Diff. in means \\
\hline \multicolumn{8}{|c|}{18 month window } \\
\hline $\operatorname{CAR}(-1,+1)$ & 106 & -0.011 & $-1.8^{*}$ & 83 & -0.0003 & -0.07 & 0.01 \\
\hline
\end{tabular}

Table A.2. CARs determinants around direct downgrades. The sample consists of 2893 downgrades issued by Moody's, S\&P and Fitch on corporate bonds of US firms from February 1999 to April 2011. The dependent variable is the cumulative abnormal return computed over a three day event window $\operatorname{CAR}(-1,+1)$. Abnormal returns are estimated using the market model in equation [1] for a 6 month estimation window. sec is a dummy equal to 1 as of January 24, 2003 when the SEC's Report is issued. rchange is the absolute magnitude of the downgrade (number of notches). sec*rchange is the interaction between sec and rchange. threshold is a binary variable equal to one if as a consequence of the downgrade a firm's security is revised from investment grade to speculative grade. days equals the logarithm of the number of days elapsing between two downgrades referring to the same firm. crisis01 and crisis07 are dummies equal to 1 in the months in which the crises occur. debt to equity, roe, log(employees) and dividend yield are controls for firms' lagged characteristics. We regress CARs associated to downgrades that are not preceded by a watchlist placement (direct downgrades), separately for Investment Grade (column 1) and Non-Investment Grade (column 2) 
securities. We control for industry and rating agency common effects. (Robust standard errors). *** indicate significance at the $1 \%$ level $* *$ at the $5 \%$ and $*$ at the $10 \%$.

\begin{tabular}{|c|c|c|}
\hline & $\begin{array}{l}1) \\
\text { Direct IG }\end{array}$ & $\begin{array}{l}(2) \\
\text { Direct NIG }\end{array}$ \\
\hline rchange & $\begin{array}{l}-0.0020 \\
(0.005)\end{array}$ & $\begin{array}{l}-0.0450 * * * \\
(0.016)\end{array}$ \\
\hline $\sec$ & $\begin{array}{l}0.0187 * * * \\
(0.006)\end{array}$ & $\begin{array}{l}0.0348 * * * \\
(0.013)\end{array}$ \\
\hline sec*rchange & $\begin{array}{l}0.0018 \\
(0.005)\end{array}$ & $\begin{array}{l}0.0313^{*} \\
(0.017)\end{array}$ \\
\hline threshold & $\begin{array}{l}-0.0302 * * * \\
(0.009)\end{array}$ & \\
\hline days & $\begin{array}{l}0.0019 \\
(0.001)\end{array}$ & $\begin{array}{l}0.0005 \\
(0.003)\end{array}$ \\
\hline debt to equity & $\begin{array}{l}-0.0006 \\
(0.000)\end{array}$ & $\begin{array}{l}-0.0002 * \\
(0.000)\end{array}$ \\
\hline roe & $\begin{array}{l}0.0054 * * \\
(0.002)\end{array}$ & $\begin{array}{l}-0.0046 * * * \\
(0.002)\end{array}$ \\
\hline log(employees) & $\begin{array}{l}-0.0011 \\
(0.002)\end{array}$ & $\begin{array}{l}-0.0018 \\
(0.004)\end{array}$ \\
\hline dividend yield & $\begin{array}{l}-0.0095^{* * * *} \\
(0.003)\end{array}$ & $\begin{array}{l}-0.0012 \\
(0.002)\end{array}$ \\
\hline crisis01 & $\begin{array}{l}0.0180 * * \\
(0.007)\end{array}$ & $\begin{array}{l}0.0346 \\
(0.023)\end{array}$ \\
\hline crisis07 & $\begin{array}{l}-0.0089 \\
(0.009)\end{array}$ & $\begin{array}{l}-0.0045 \\
(0.011)\end{array}$ \\
\hline Constant & $\begin{array}{l}0.0240 \\
(0.026)\end{array}$ & $\begin{array}{l}-0.0812 * \\
(0.045)\end{array}$ \\
\hline Observations & 980 & 786 \\
\hline Industry dummies & Yes & Yes \\
\hline Agency dummies & Yes & Yes \\
\hline R-squared & 0.137 & 0.104 \\
\hline Adj. R-squared & 0.110 & 0.0725 \\
\hline $\mathrm{F}$ & 2.089 & 1.815 \\
\hline
\end{tabular}


Table A.3. Downgrade and non-downgrade's days analysis. The overall sample consists of 5040 rating actions (2915 downgrades, 2125 upgrades) issued by Moody's, S\&P and Fitch on corporate bonds of US firms from August 1998 to April 2011 and it also includes 2,110,522 days when no rating change takes place. The dependent variable is the cumulative abnormal return computed over a three day event window CAR(-1, +1$)$. Abnormal returns are estimated using the value-weighted market adjusted model. sec is a dummy equal to 1 as of January 24, 2003 when the SEC's Report is issued. neg is a dummy equal to 1 if $\operatorname{CAR}(-1,+1)<0$ and zero otherwise. down and up are dummies equal to 1 respectively when the CAR is associated to a downgrade or an upgrade. crisis01 and crisis07 are dummies equal to 1 in the months in which the crises occur according to NBER business cycle dates; debt to equity, roe, log(employees) and dividend yield are controls for firms' lagged characteristics. Column 1 tests the impact of rating changes (RC) on CARs using as controls about 6,000 days randomly chosen among those where no rating change takes place (NRC). Column 2 tests for a change in the significance of positive and negative CARs associated to upgrades before and after the SEC's Report using interactions between the dummies sec and neg. Columns 3 does the same for downgrades. (Robust standard errors). *** indicate significance at the $1 \%$ level $* *$ at the $5 \%$ and $*$ at the $10 \%$.

\begin{tabular}{|c|c|c|c|}
\hline & $\begin{array}{l}(1) \\
\text { RC and NRC days }\end{array}$ & $\begin{array}{l}(2) \\
\text { Upgrades } \\
\end{array}$ & $\begin{array}{l}(3) \\
\text { Downgrades }\end{array}$ \\
\hline $\sec$ & $\begin{array}{l}0.0006 \\
(0.002)\end{array}$ & $\begin{array}{l}-0.0166 * * * \\
(0.004)\end{array}$ & $\begin{array}{l}-0.0100 * \\
(0.006)\end{array}$ \\
\hline down & $\begin{array}{l}-0.0279 * * * \\
(0.005)\end{array}$ & & \\
\hline up & $\begin{array}{l}0.0041 \\
(0.003)\end{array}$ & & \\
\hline sec*down & $\begin{array}{l}0.0154 * * * \\
(0.005)\end{array}$ & & \\
\hline sec*up & $\begin{array}{l}-0.0023 \\
(0.004)\end{array}$ & & \\
\hline neg & & $\begin{array}{l}-0.0815^{* * *} \\
(0.005)\end{array}$ & $\begin{array}{l}-0.1418 * * * \\
(0.008)\end{array}$ \\
\hline sec*neg & & $\begin{array}{l}0.0266^{* * * *} \\
(0.005)\end{array}$ & $\begin{array}{l}0.0474 * * * \\
(0.008)\end{array}$ \\
\hline debt to equity & $\begin{array}{l}-0.0000 * * \\
(0.000)\end{array}$ & $\begin{array}{l}0.0000 \\
(0.000)\end{array}$ & $\begin{array}{l}-0.0000^{* *} \\
(0.000)\end{array}$ \\
\hline roe & $\begin{array}{l}-0.0000 \\
(0.000)\end{array}$ & $\begin{array}{l}-0.0000^{*} \\
(0.000)\end{array}$ & $\begin{array}{l}0.0000 \\
(0.000)\end{array}$ \\
\hline $\log$ (employees) & $\begin{array}{l}-0.0007 \\
(0.001)\end{array}$ & $\begin{array}{l}-0.0005 \\
(0.001)\end{array}$ & $\begin{array}{l}0.0003 \\
(0.002)\end{array}$ \\
\hline dividend yield & $\begin{array}{l}0.0005 \\
(0.000)\end{array}$ & $\begin{array}{l}0.0000 \\
(0.000)\end{array}$ & $\begin{array}{l}0.0014 \\
(0.001)\end{array}$ \\
\hline crisis 01 & $\begin{array}{l}0.0037 \\
(0.004)\end{array}$ & $\begin{array}{l}-0.0026 \\
(0.005)\end{array}$ & $\begin{array}{l}0.0072 \\
(0.007)\end{array}$ \\
\hline crisis07 & $\begin{array}{l}-0.0027 \\
(0.002)\end{array}$ & $\begin{array}{l}0.0036 \\
(0.003)\end{array}$ & $\begin{array}{l}-0.0068 \\
(0.005)\end{array}$ \\
\hline Constant & $\begin{array}{l}0.0025 \\
(0.006)\end{array}$ & $\begin{array}{l}-0.0322 * * * \\
(0.009)\end{array}$ & $\begin{array}{l}-0.0923 * * * \\
(0.020)\end{array}$ \\
\hline Observations & 9,524 & 1,746 & 2,490 \\
\hline Industry dummies & Yes & Yes & Yes \\
\hline R-squared & 0.020 & 0.443 & 0.303 \\
\hline Adj. R-squared & 0.0172 & 0.435 & 0.296 \\
\hline $\mathrm{F}$ & 4.140 & 63.27 & 54.17 \\
\hline
\end{tabular}


Table A4. Distribution of downgrades associated with CDSs trading on firm's debt, from Chava et al. (2015) table IA1 Panel A.

\begin{tabular}{ll} 
year & fraction of downgrades associated with CDS \\
\hline 1996 & 0.00 \\
1997 & 0.00 \\
1998 & 0.00 \\
1999 & 0.00 \\
2000 & 0.00 \\
2001 & 0.02 \\
2002 & 0.12 \\
2003 & 0.33 \\
2004 & 0.45 \\
2005 & 0.54 \\
2006 & 0.63 \\
2007 & 0.64 \\
2008 & 0.72 \\
2009 & 0.59 \\
2010 & 0.55 \\
\hline \hline
\end{tabular}


Table A.5. The dependent variable is the cumulative abnormal return computed over a three day event window CAR(-1, +1). sec is a dummy equal to 1 as of January 24, 2003, when the SEC's Report is issued. percCDSoveryear is the number of downgrades to issues associated to CDSs over the total number of downgrades in a given year in the sample of Chava et al. (2015). rchange is the absolute magnitude of the downgrade (number of notches); negative watch is a dummy variable equal to 1 when the downgrade is preceded by a negative watch; investment grade is a dummy equal to 1 if the downgraded security was deemed investment grade before the downgrade, threshold is a binary variable equal to one if as a consequence of the downgrade a firm's security is revised from investment grade to speculative grade; days equals the logarithm of the number of days elapsing between two downgrades referring to the same firm; crisis01 and crisis07 are dummies equal to 1 in the months in which the crises occur ; debt to equity, roe, $\log$ (employees) and dividend yield are controls for firms' lagged characteristics; we further control for industry and rating agency (Fitch, Moody's, S\&P) common effects. (Robust standard errors). *** indicate significance at the $1 \%$ level $* *$ at the $5 \%$ and $*$ at the $10 \%$.

\begin{tabular}{|c|c|c|c|}
\hline & $\begin{array}{l}(1) \\
\text { CAR_11 }\end{array}$ & $\begin{array}{l}(2) \\
\text { CAR_11 }\end{array}$ & $\begin{array}{l}(3) \\
\text { CAR_11 }\end{array}$ \\
\hline rchange & $\begin{array}{l}-0.0057 * * \\
(0.003)\end{array}$ & $\begin{array}{l}-0.0057^{*} \\
(0.003)\end{array}$ & $\begin{array}{l}-0.0057 * * \\
(0.003)\end{array}$ \\
\hline $\mathrm{sec}$ & & $\begin{array}{l}0.0287 * * \\
(0.012)\end{array}$ & $\begin{array}{l}0.0252 * \\
(0.013)\end{array}$ \\
\hline percCDSoveryear & $\begin{array}{l}0.0249 * * \\
(0.010)\end{array}$ & $\begin{array}{l}-0.0263 \\
(0.021)\end{array}$ & $\begin{array}{l}-0.0474 \\
(0.071)\end{array}$ \\
\hline secXCDSoveryear & & & $\begin{array}{l}0.0251 \\
(0.072)\end{array}$ \\
\hline negative watch & $\begin{array}{l}0.0134 * * * \\
(0.005)\end{array}$ & $\begin{array}{l}0.0142 * * * \\
(0.005)\end{array}$ & $\begin{array}{l}0.0146 * * * \\
(0.005)\end{array}$ \\
\hline investment grade & $\begin{array}{l}0.0160 * * \\
(0.007)\end{array}$ & $\begin{array}{l}0.0163 * * \\
(0.008)\end{array}$ & $\begin{array}{l}0.0160 * * \\
(0.008)\end{array}$ \\
\hline threshold & $\begin{array}{l}-0.0233 * * * \\
(0.008)\end{array}$ & $\begin{array}{l}-0.0233^{* * *} \\
(0.008)\end{array}$ & $\begin{array}{l}-0.0231^{* * *} \\
(0.008)\end{array}$ \\
\hline days & $\begin{array}{l}0.0018 \\
(0.001)\end{array}$ & $\begin{array}{l}0.0018 \\
(0.001)\end{array}$ & $\begin{array}{l}0.0018 \\
(0.001)\end{array}$ \\
\hline debt to equity & $\begin{array}{l}-0.0002 * * \\
(0.000)\end{array}$ & $\begin{array}{l}-0.0002 * * \\
(0.000)\end{array}$ & $\begin{array}{l}-0.0002 * * \\
(0.000)\end{array}$ \\
\hline roe & $\begin{array}{l}-0.0028^{* *} \\
(0.001)\end{array}$ & $\begin{array}{l}-0.0027 * * \\
(0.001)\end{array}$ & $\begin{array}{l}-0.0028 * * \\
(0.001)\end{array}$ \\
\hline $\log ($ employees $)$ & $\begin{array}{l}-0.0005 \\
(0.002)\end{array}$ & $\begin{array}{l}-0.0006 \\
(0.002)\end{array}$ & $\begin{array}{l}-0.0006 \\
(0.002)\end{array}$ \\
\hline dividend yield & $\begin{array}{l}0.0001 \\
(0.003)\end{array}$ & $\begin{array}{l}0.0001 \\
(0.003)\end{array}$ & $\begin{array}{l}0.0001 \\
(0.003)\end{array}$ \\
\hline crisis 01 & $\begin{array}{l}0.0196 * * \\
(0.008)\end{array}$ & $\begin{array}{l}0.0206^{* *} \\
(0.008)\end{array}$ & $\begin{array}{l}0.0199 * * \\
(0.009)\end{array}$ \\
\hline crisis07 & $\begin{array}{l}-0.0058 \\
(0.007)\end{array}$ & $\begin{array}{l}-0.0007 \\
(0.008)\end{array}$ & $\begin{array}{l}-0.0013 \\
(0.008)\end{array}$ \\
\hline Constant & $\begin{array}{l}-0.0327 \\
(0.024)\end{array}$ & $\begin{array}{l}-0.0306 \\
(0.024)\end{array}$ & $\begin{array}{l}-0.0290 \\
(0.025)\end{array}$ \\
\hline Observations & 2,424 & 2,424 & 2,424 \\
\hline R-squared & 0.031 & 0.033 & 0.033 \\
\hline Industry dummies & Yes & Yes & Yes \\
\hline Agency dummies & Yes & Yes & Yes \\
\hline Adj. R-squared & 0.0188 & 0.0207 & 0.0203 \\
\hline $\mathrm{F}$ & 2.099 & 2.093 & 2.060 \\
\hline
\end{tabular}




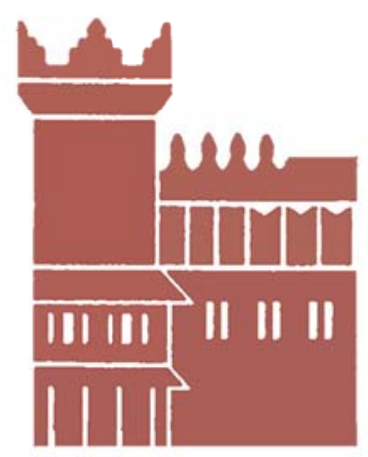

Alma Mater Studiorum - Università di Bologna DEPARTMENT OF ECONOMICS

Strada Maggiore 45

40125 Bologna - Italy

Tel. +39051 2092604

Fax +390512092664

http://www.dse.unibo.it 